\title{
Process Strategies for the Transition of 1G to Advanced Bioethanol Production
}

\author{
Ana Susmozas ${ }^{1}\left(\mathbb{D}\right.$, Raquel Martín-Sampedro ${ }^{2,3}{ }^{\circledR}$, David Ibarra ${ }^{3}{ }^{(D}$, María E. Eugenio $^{3}$, \\ Raquel Iglesias ${ }^{1}$ (D), Paloma Manzanares ${ }^{1}\left(\mathbb{D}\right.$ and Antonio D. Moreno ${ }^{1, *(\mathbb{D}}$ \\ 1 Advanced Biofuels and Bioproducts Unit, Department of Energy, Research Centre for Energy, \\ Environment and Technology (CIEMAT), 28040 Madrid, Spain; anaisabel.susmozas@ciemat.es (A.S.); \\ raquel.iglesias@ciemat.es (R.I.); p.manzanares@ciemat.es (P.M.) \\ 2 Institute of Materials Science of Madrid (ICMM), Spanish National Research Council (CSIC), 28049 Madrid, \\ Spain; r.martin.sampedro@csic.es \\ 3 Forestry Products Department, Forest Research Centre (CIFOR), National Institute for Agricultural and Food \\ Research and Technology (INIA), 28040 Madrid, Spain; ibarra.david@inia.es (D.I.); \\ mariaeugenia@inia.es (M.E.E.) \\ * Correspondence: david.moreno@ciemat.es; Tel.: +34-91-346-6054
}

Received: 15 September 2020; Accepted: 12 October 2020; Published: 19 October 2020

check for updates

\begin{abstract}
Nowadays, the transport sector is one of the main sources of greenhouse gas (GHG) emissions and air pollution in cities. The use of renewable energies is therefore imperative to improve the environmental sustainability of this sector. In this regard, biofuels play an important role as they can be blended directly with fossil fuels and used in traditional vehicles' engines. Bioethanol is the most used biofuel worldwide and can replace gasoline or form different gasoline-ethanol blends. Additionally, it is an important building block to obtain different high added-value compounds (e.g., acetaldehyde, ethylene, 1,3-butadiene, ethyl acetate). Today, bioethanol is mainly produced from food crops (first-generation (1G) biofuels), and a transition to the production of the so-called advanced ethanol (obtained from lignocellulosic feedstocks, non-food crops, or industrial waste and residue streams) is needed to meet sustainability criteria and to have a better GHG balance. This work gives an overview of the current production, use, and regulation rules of bioethanol as a fuel, as well as the advanced processes and the co-products that can be produced together with bioethanol in a biorefinery context. Special attention is given to the opportunities for making a sustainable transition from bioethanol $1 \mathrm{G}$ to advanced bioethanol.
\end{abstract}

Keywords: bioeconomy; integrated biorefineries; biomass; bioethanol; retrofitting

\section{Introduction}

One of the most important priorities in today's society is the implementation of a sustainable bio-based economy aiming at reducing the global greenhouse gas (GHG) emissions, the alarming increase in global energy demand, and the depletion of fossil fuel reserves. In this context, biomass is a renewable, abundant, and widely distributed raw material considered as an important alternative for the production of biofuels and a great variety of bio-products (e.g., chemicals, materials, food, and feed). Among the different options, bioethanol is the most widespread and most used liquid biofuel, especially in the transport sector [1]. According to 2016 data, $41.5 \%$ of the global $\mathrm{CO}_{2}$ emissions were related to this sector [2], and the use of biofuels, such as bioethanol, can therefore help to drastically decrease those numbers.

Ethanol $\left(\mathrm{C}_{2} \mathrm{H}_{6} \mathrm{O}\right)$, also known as ethyl alcohol, is a volatile, colorless, and flammable liquid at room temperature. In addition to being considered as a fuel, ethanol is also an antiseptic, a solvent, 
a psychoactive drug, and a precursor for other organic compounds, such as ethylene, acetaldehyde, etc. [3,4]. Ethanol as a fuel is not a novel concept since it was already used by Henry Ford to run his Model $\mathrm{T}$ at the early 20th century. The main reasons to consider ethanol as an excellent alternative to oil-derived fuels are the following: (i) it can be obtained from renewable raw materials; (ii) it is less toxic than other alcoholic fuels (e.g., butanol); (iii) it can be used directly in cars mixed with gasoline in different ratios; (iv) it has lower emissions of pollutants than fossil fuels because the oxygen that it contains improves the combustion; and (v) the resulting byproducts from incomplete oxidation (e.g., acetic acid, acetaldehyde) have lower toxicity power than those formed from other alcohol fuels $[5,6]$.

Bioethanol has been traditionally produced from sugar- or starch-containing raw materials in what has been called first-generation (1G) bioethanol [7]. However, concerns on the sustainability of the use of food-related feedstock in the energy industry have promoted in the last decades the search for alternative raw materials. Those include lignocellulosic biomass, industrial-derived wastes, algal biomass, syngas, and bio-based glycerol as promising raw materials for the production of what has been called advanced bioethanol. The present work discusses firstly the current regulation framework for bioethanol production and use and the aspects related to the sustainability of this biofuel. Next, the most attractive strategies for advanced bioethanol production as an alternative to $1 \mathrm{G}$ bioethanol production processes are shown, as well as the potential added-value co-products that contribute to the cost-effectiveness of these technologies within a biorefinery concept.

\section{The Bioethanol Business: Regulation and Sustainability}

\subsection{Global Bioethanol Industry Scenario}

The necessity of introducing renewable energy in the transport sector is out of the question taking into account that the energy consumption for this sector accounts to about one third of the total energy consumption globally (13,978 Mtoe in 2018) [8]. Liquid biofuels are playing a key role for the evolution of a sector that is still dominated by a massive use of fossil fuels. Liquid biofuels, mainly biodiesel and bioethanol, have been steadily growing in the energy market in the last decades, although the penetration level still remains low. According to the REN21 International Network [9], liquid biofuels represented 3\% of the total final energy consumption (TFEC) in the transport sector in 2016. The increase in biofuel utilization for transportation remains restrained by policy uncertainties related to feedstock and other sustainability concerns, since most biofuels are currently produced by conventional processes from food crops (1G biofuels). The development of advanced biofuels based on non-food feedstocks are expected to significantly contribute to the liquid biofuels' quota. However, the cost-competitiveness is significantly lower than that of conventional fuels because they are just at the start of their commercialization [10].

Bioethanol is the largest renewable energy contributor in global transportation. In 2019, the production of this biofuel reached 110,000 million L globally [11]. Ethanol can be blended with gasoline at different proportions. Mixtures of gasoline with ethanol at 10\% (E10) cover the majority of the international demand, although higher ethanol blends (E15-E85) can also be found in minor proportions due to limitations in the fuel-supply structure and vehicle compatibility. An overview of the main players in the bioethanol market can be seen in Figure 1, which depicts the contribution of the major world ethanol producers to the total global production in 2019. The United States leads the world ethanol supply and demand with a $54 \%$ share from the total global production. Roughly, $10 \%$ of the production is exported, with Brazil and Canada being the top customers of US ethanol exports.

Brazil is the second world ethanol producer with a total amount of 32,000 million L in 2019 (about $30 \%$ of the global production). A great part of this production is nowadays consumed in the domestic market, either in the form of pure ethanol fuel or blended with gasoline. Anhydrous ethanol is mainly used in mixtures with gasoline (typically containing $27 \%$ of anhydrous ethanol), accounting for about $38 \%$ of the total national ethanol consumption in this country, while hydrous ethanol is traded as a standard fuel [12]. Despite being a world-leading ethanol producer (obtained mainly from sugarcane), 
Brazil imports ethanol from the USA (produced from corn) due to competitive prices [13]. Brazil's total ethanol imports for 2019 were 1200 million L, while the total US ethanol exports were estimated at 1800 million L, increasing the total exportation from 2018 by $11 \%$ according to USDA Foreign Agricultural Service [14].



$$
\begin{aligned}
& \text { - United States } \\
& \text { - Brazil } \\
& \text { - China } \\
& \text { - Argentina } \\
& \text { - Thailand } \\
& \text { - Canada } \\
& \text { India } \\
& \text { Europe } \\
& \text { nest of world }
\end{aligned}
$$

Figure 1. Production of fuel ethanol by country (share of global production) in 2019. Adapted from: 2020 Ethanol Industry Outlook. Renewable Fuel Association (RFA) [11].

The European Union follows the USA and Brazil in ethanol production levels, reaching 5443 million L in 2019 (5\% of the global production). Most of the gasoline in Europe is in the form of the E5 blend, although E10 represents an increasing share of the market. E10 has been progressively rolled out across Europe since 2009 and is currently available in several EU countries, including Belgium, Bulgaria, Denmark, Estonia, Finland, France, and Germany. Moreover, according to e-Pure Association data [15], in 2018, Europe imported 618 million L ethanol from Pakistan (20.6\%), the United States (16.4\%), Guatemala (13.8\%), and Brazil (11.8\%).

Finally, it is important to highlight the rapid expansion of the ethanol production capacity in China that reached 3403 million $\mathrm{L}$ in 2019. China is expecting to have a national E10 mandate for the domestic use of this blend from 2020, and several plants are projected or under construction to meet this growing demand. Moreover, Chinese-based companies are expanding their technology at the international level, such as, for example, in Nigeria [9].

\subsection{Regulation Rules for Bioethanol Production and Use: The Case of the European Union and the United States}

Policies to promote the production and use of biofuels are the main factors driving the rate of bioethanol growth at an international level. Additionally, fossil fuel prices clearly influence the dynamics of biofuels and, hence, of the bioethanol market. Among the different forms of policy tools currently being used, blending mandates stand out as the most widely adopted instrument to increase the production and use of bioethanol, although other mechanisms, such as fiscal incentives and public financing means, are also being applied [16]. The regulation rules and policies vary among specific countries and world regions with different forms of mandates and targets for the use of bioethanol as a fuel.

The EU has been promoting in the last decades the use of biofuels, including bioethanol, through a series of directives and supporting rules. The first directive was implemented in 2003, setting an indicative biofuel penetration target of $2 \%$ by the end of 2005 and $5.75 \%$ by the end of 2010. In 2009, the first EU Renewable Energy Directive (RED) [17] mandated that $10 \%$ of energy used in the transportation sector should come from renewable energy sources (RESs) by 2020. Later, in 2016, the European Commission updated this directive for the 2021-2030 period, reaching a final agreement in 2018. As a consequence, a revised Renewable Energy Directive 2018/2001/EU (RED II) [18] entered into force at the end of that year, increasing the renewable energy target in EU to 32\% by 2030, with the chance of revision by 2023. RED II introduces a total 14\%-RES energy target for transportation in 2030, with a particular 3.5\% sub-target for advanced biofuels. In addition, conventional food-based biofuels, including bioethanol, will be restricted to a maximum of 7\% at each member state's 2020 level. 
As a result, a minimum target of $7 \%$ is therefore considered for advanced non-food-based biofuels. This EU directive must now be implemented at the national level, and each country will set up the conditions and procedures to guarantee these obligatory targets by using the corresponding policy instruments [19].

In the USA, the main force contributing to deploy bioethanol production and use was the Energy Policy Act of 2005, further extended by the Energy Independence and Security Act (EISA) of 2007. It originated the Renewable Fuel Standard (RFS) federal program, which required fuel blends in transportation with renewable biofuels (both conventional and advanced biofuels). According to the Renewable Fuels Association (RFA) [20], "the legislation that originated RFS was the first time that low carbon fuels were required anywhere in the world. It sent a powerful signal to the market that motivated investors and technology developers alike and created today's dynamic and growing biofuels industry in USA". Additionally, RFA considers that RFS "has helped to create an added-value market for farmers, assure growth for biofuels like ethanol and address critical environmental and energy security priorities".

US biofuels (mostly corn ethanol) are currently near $10 \%$ of the country gasoline supply level, which has been referred to as the 'blend wall'. The RFS has projected annual increasing amounts of biofuels blends into transportation, rising to ca. 136,000 million L by 2022 (Figure 2). Nonetheless, the objectives of RFS have not been met since 2014, and particularly, advanced biofuel has not reached the statutory target since 2015. In the USA, RFS is administered by the Environmental Protection Agency (EPA), which is in charge of assessing which renewable fuels are eligible for the RFS program. Additionally, EPA fixes the amount of renewable fuel that will be required for the next year based on the statutory targets, fuel supply, and other conditions. In 2020, for example, EPA established a final total volume of renewable fuels of 76,000 million L (20.09 US billion gallons), of which 56,800 million L (15 US billion gallons) stand for conventional bioethanol from corn and 2200 million L (0.59 US billion gallons) for cellulosic ethanol. As depicted in Figure 2, the total target value is significantly lower than the projected volume for 2020 (32 US billion gallons), with the cellulosic ethanol shortfalls being the main reason for these differences.

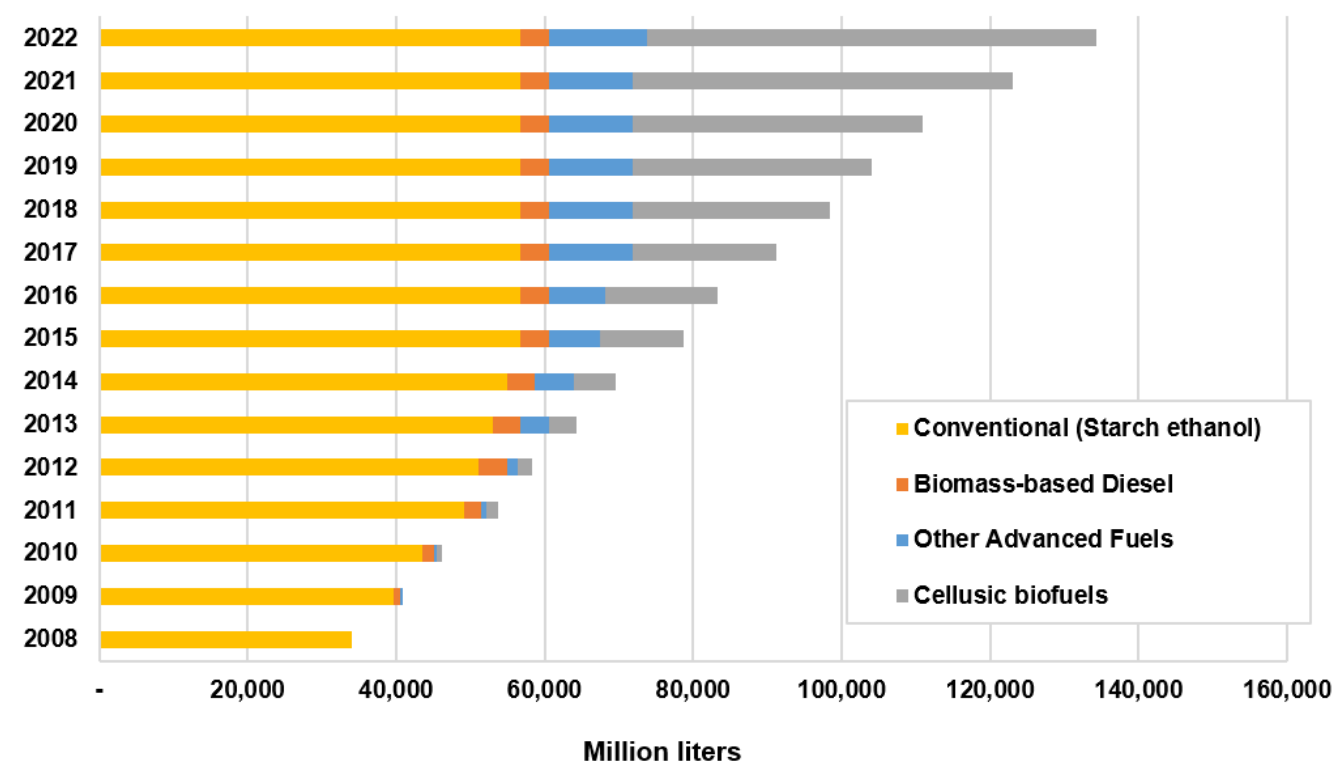

Figure 2. Predictable Renewable Fuels Association (RFA) volumes by year in the USA. Source: U.S. Department of Energy (https://afdc.energy.gov/laws/RFS.html).

Apart from regulating the use of biofuels in substitution to fossil fuels in the transport sector, most policies are beginning to introduce sustainability criteria affecting the production chain of biofuels. Some aspects of this key issue are described below. 


\subsection{Considerations on the Sustainability of Bioethanol Production}

The growth of bioethanol (and biofuels in general) consumption in the transport sector has often been constrained by certain sustainability concerns involving environmental issues regarding their production and use. To overcome such a handicap, a big effort has been carried out to develop robust tools aimed at assessing the energy and carbon balances for the production and use of biofuels and their impact to the environment. Additionally, measuring the social benefits of biofuels is crucial, since they represent an opportunity for the development of rural areas and to create new jobs [21]. The impact of a growing demand of feedstocks for biofuels in the economy and commodity markets needs to be evaluated as well. Thus, an overall sustainability analysis of the whole biofuel chain must contemplate environmental, economic, and social implications and provide quantitative assessments that could be used as instruments to facilitate policy decisions for implementing and accelerating the commercialization and adoption of conventional and advanced biofuels. On this subject, all thoughts related to biofuels' sustainability can be considered to directly affect bioethanol as it is one of the main biofuels used worldwide.

At the European level, the RED issued in 2009 set out for the first time the sustainability criteria for all biofuels produced or consumed in the EU. This RED required a 35\% GHG emission savings from the use of biofuels in comparison to fossil fuels. According to the directive, the agricultural biomass used for biofuel production must not came from materials originating from high biodiversity land, high carbon stock land, and land considered as peatland in January 2008 [18].

The competition of the land for food/feed or energy purposes is a particular sensitive aspect of bioethanol production, which clearly affects its overall sustainability. Since current commercial bioethanol production is mostly based on food crops, its impact in the global food price dynamics has been the subject of considerable debate since 2007. In the particular case of bioethanol, an intense food versus fuel discussion was raised at the end of the decade of the 2010s, with severe charges to provoke food insecurity on a global scale due to expansive use of cereal grain in Europe and the USA for its production [22]. The wide discussion on the role of biofuel prices in food shortages has generated a series of publications and reports against and in favor of biofuels' deployment [23,24], resulting in what Rosillo-Calle [25] claimed as two main schools of thoughts: (i) the 'antibiofuels lobby' and (ii) the 'probiofuels lobby'. The strong debate and the explosion of food commodity prices in 2008 and 2011 served as driver to reform the EU policy. In 2015, amendments to the RED directive were introduced with the Indirect Land Use Change (ILUC) directive [26], which establishes ILUC values for biofuels and more restrictive sustainability criteria to the original RED directive. ILUC occurs when pasture or agricultural land previously destined for food and feed markets is diverted to biofuel production; the non-fuel demand will still need to be satisfied either through intensification of current production or by bringing non-agricultural land into production elsewhere. The release of $\mathrm{CO}_{2}$ stored in trees and soil that may occur as a consequence of this shift put in danger the GHG savings that arise from the use of biofuels. This issue was addressed in the 2015 directive, assigning ILUC factors to different biofuels but only for reporting purposes.

In acceptance of the negative impact that $1 \mathrm{G}$ biofuels may have in food prices, EU has given a step forward in sustainability regulation and after several amendments to previous rules, the RED II Directive establishes that in 2030, conventional food-based biofuels, including bioethanol, will be topped at each member state's 2020 level with an additional 1\%, setting a maximum of 7\%. As RED II establishes a $14 \%$ of RES, it means that a minimum $7 \%$ target for advanced non-food-based biofuels can be considered. Additionally, fuels obtained from feedstocks with 'high ILUC risk' will be further restricted at the 2019 consumption level and gradually reduced to $0 \%$ by 2030 [18]. Moreover, the GHG emissions reduction threshold for biofuels has also been increased to $65 \%$.

In the USA, the EISA set up different life cycle GHG emissions thresholds for each category, requiring a percentage of improvement in relation to the baseline emissions of gasoline and diesel. EISA establishes a minimum of a $20 \%$ reduction of life-cycle-GHG emissions for corn starch ethanol and biodiesel in relation to life-cycle emissions from fossil fuels, while advanced biofuels have to 
decrease GHG emissions by $50 \%$ and cellulosic biofuels by $60 \%$. EISA also provides several types of funds for research activities in this field, biorefineries substituting more than $80 \%$ of fossil fuels used in own operations, and commercial applications of cellulosic ethanol. As the RFS program requires the sale of specified volumes of renewable fuels according to the categories above, EPA performs a strict assessment of each fuel 'pathway' that is proposed to qualify for the RFS, regarding the GHG emission reduction required, according to the US Sustainability Alliance organization [27].

In relation to the methodologies employed to assess biofuels' sustainability, the most predominant tool is life cycle analysis (LCA). LCA is a well-known methodology for evaluating the global environmental performance of a product or process throughout its partial or whole life cycle, taking into account the different impacts generated. Based on the use of LCA procedure, a series of life cycle sustainability assessment (LCSA) models have been developed, which consider the environmental impacts of the system together with the economic and social impacts [28,29]. Recently, the International Energy Agency (IEA), through the IEA Bioenergy Organization, has revised and compared five leading LCA models used to assess biofuels sustainability in the USA, Canada, Brazil, and Europe. The authors claimed that the discrepancies found among the different models are primarily based on the default values within each model and the related assumptions, which must be standardized to get comparable results [30].

While being valid and useful instruments, LCSA models are time and data intensive [21]. In this context, certification schemes are often used by policy makers in many countries to assess the sustainability of products such as biofuels. They are simpler tools to establish the main features, criteria, or indicators that a specific product must fulfill. In the case of biofuels, certification may be the precondition for products to be counted towards national targets [31]. In Europe, companies can use national certification systems or the so-called voluntary schemes (14 in total; https:/ec.europa.eu/energy/ topics/renewable-energy/biofuels/voluntary-schemes) to prove compliance with the sustainability criteria. Examples of EU-approved certification systems related to bioethanol sustainability are the scheme RSB EU RED, developed by the Roundtable on Sustainable Biomaterials (RSB), a global, multi-stakeholder, and independent organization, and the 2BSys scheme developed by the French operator association 2BS.

\section{Overview of Current Bioethanol Production Processes}

Most of the ethanol obtained nowadays comes from sugar and starch-based feedstocks, such as corn, grain, or sugarcane (1G bioethanol). The conversion of these raw materials is relatively simple compared to advanced production processes, and there are well-established technologies to obtain the corresponding free sugars and transform them into bioethanol.

Major 1G bioethanol production processes were previously reviewed by Vohra and coworkers [32]. The process scheme of these technologies includes specific steps for an optimal sugar release depending on the type of biomass. Sugar-based feedstocks (e.g., sugarcane, sugar beets, sweet sorghum) basically require a chopping/milling process to release their sugar components, resulting in high sugar titers and yields. In the process used in sugarcane mills, sugar stalks are crushed with specialized rollers to release the sugar-rich juice. The resulting juice is then treated with lime $\left(\mathrm{Ca}(\mathrm{OH})_{2}\right)$ for clarification (precipitation of the fiber and the sludge), and is subsequently filtered and evaporated to concentrate and crystallize the sugar. The non-crystallized sugar fraction, known as molasses, is then subjected to fermentation with the yeast Saccharomyces cerevisiae at about $30-35^{\circ} \mathrm{C}$ and at a sugar concentration of $14-18 \%$ [33]. Due to the absence of solid particles, this process offers the possibility of yeast recycling, which allows having a high cell density during the fermentation step and reduces the process time by $6-10 \mathrm{~h}$. Overall, this process may yield $75-100 \mathrm{~L}$ of ethanol per ton of biomass depending on the raw material [32,34]. This technology is mainly used in tropical areas, including Brazil, India, and Colombia [35]. Although the technology is commercial and well developed, there are still a few points that can be optimized [36]. The selection of new substrate varieties to increase the amount of total sugar per ton of biomass and/or to yield higher amounts of biomass per cultivated hectare are among the 
main goals and is also a top priority for sugarcane breeding programs worldwide. Furthermore, the development of new fermentative strains with increased robustness towards the stressing conditions and the prevention of bacterial and yeast contamination during fermentation stage are also key aspects for process improvement.

In contrast to sugar-based feedstocks, starch-based raw materials (e.g., corn, wheat, rice, cassava) require liquefaction and saccharification steps to hydrolyze carbohydrates into the corresponding sugar monomers [3,32]. In the specific case of corn, there are two different processing methods, dry milling and wet milling. Dry mills are mainly built to produce ethanol and are usually smaller in capacity, while wet mills are designed to also obtain certain co-products, such as high-fructose corn syrup (HFCS), dextrose, and glucose syrup. During the corn dry-milling process, the raw material is first ground to fine particles to ease the subsequent liquefaction step. Liquefaction takes places at $85^{\circ} \mathrm{C}(1-2 \mathrm{~h})$ after mixing the ground substrate with water and supplementing such a mixture with $\alpha$-amylase enzymes (EC 3.3.1.1). Subsequently, the mixture is cooled down to $30-35^{\circ} \mathrm{C}$ and supplemented with yeast (commonly S. cerevisiae) and glucoamylase enzymes (EC 3.2.1.3) for a simultaneous saccharification and fermentation (SSF) process that lasts $40-50 \mathrm{~h}$ [37]. This integration strategy minimizes the risk of contamination since glucose is consumed at the same time that it is being released and reduces equipment requirements, which benefits the overall costs. After distillation, the resulting protein-rich stillage is typically dried to a $27 \%$ protein product known as distillers dried grains with solubles (DDGS), which is used for animal feeding [32]. In contrast to the dry-milling process, the wet-milling process aims at fractionating corn kernels into the hull, the germ, and the endosperm to obtain, in addition to ethanol, the aforementioned co-products. Corn is the main feedstock worldwide for bioethanol production, since it is the most used substrate in the United States (the first bioethanol producer) [9]. In addition, wheat and rice are also important raw materials, especially in Europe and China, respectively [38]. Overall, these processes may yield up to $400 \mathrm{~L}$ of ethanol per ton of corn [34]. This yield is about 4 -fold higher than that obtained with sugar-based feedstocks. However, it should be noted that sucrose is the primary product in the sugarcane-based industry what influences the final ethanol yields.

The starch-based industry has been implementing and developing novel approaches to improve process performance and economic competitiveness, including new processing strategies and the use of novel fermentative strains and enzymes with higher efficiencies. Enzymatic hydrolysis in starch-based conversion processes is essential. Research efforts have been focused on obtaining genetically modified corn variants that may accumulate starch-hydrolyzing enzymes, giving the possibility of reducing the amount of external enzyme added to the process. This strategy was developed by Syngenta company (Basel, Switzerland)), which created a new corn variety named as 'corn amylase' capable of expressing a thermostable $\alpha$-amylase in the endosperm [39]. With the aim of further improving this concept, Kumar and Singh [40] developed a new genetically modified S. cerevisiae strain that expresses an exogenous glucoamylase to reduce external enzyme addition even more. The use of both corn amylase and the glucoamylase-expressing strain, combined with a continuous ethanol removal method, resulted in complete sugar consumption at a substrate concentration as high as $40 \%$, increasing the final ethanol yield by $65 \%$ and reducing enzyme requirements by $80 \%$ when compared to a similar process using conventional technology.

In addition to sugar- and starch-based feedstocks, lignocellulose has been extensively studied for the production of what is called cellulosic ethanol. In the context of this work, cellulosic ethanol will be referred to as second-generation $(2 \mathrm{G})$ bioethanol, although it is acknowledged that the latter maybe understood as a broader concept. In 2013, the first commercial 2G bioethanol plant in Europe was commissioned by Beta Renewables in Crescentino (Italy) [41]. Lignocellulosic biomass includes forestry and agricultural residues, dedicated crops, the organic fraction of municipal solid wastes, and other industrial wastes as major representatives. In contrast to $1 \mathrm{G}$ bioethanol production processes, where the cost of the raw material accounts for the $40-70 \%$ of the total cost [42], lignocellulosic feedstocks may represent about $30 \%$ of the total production costs [43]. Furthermore, these raw materials may 
be of residual origin and they do not compete with food products. One of the main constraints of $2 \mathrm{G}$ conversion processes lies in the recalcitrant nature of lignocellulosic substrates. This hinders the accessibility of enzymes to the carbohydrates and prevents sugar release. Therefore, more intensive processes are required to improve conversion yields (e.g., a pretreatment step is required prior to saccharification and fermentation, higher enzyme loadings are needed, etc.), which increase the overall process costs of $2 \mathrm{G}$ technology and highly influence product prices [44,45]. More details about 2G conversion technology can be found in Section 4.1, which highlights the recent progress towards developing more competitive $2 \mathrm{G}$ bioethanol production processes.

Production costs of $2 \mathrm{G}$ biofuels are highly variable, depending on the conversion technology and the raw material used [46]. In the particular case of $2 \mathrm{G}$ bioethanol, estimated costs fall in the range of 103-158 EUR/MWh (0.60-0.92 EUR/L) [43], considering capital costs (38-41\%), feedstock costs (31-32\%), and operating costs (27-30\%). These high production costs therefore represent a strong limitation and have been critical for the success of the technology. Table 1 lists the $2 \mathrm{G}$ bioethanol plants that have been placed worldwide, summarizing raw materials, production capacity, and their current status.

Due to the high production costs and other economy and energy market-related factors, about half of the total $2 \mathrm{G}$ plants constructed have ceased operation, while other planned plants were stopped during construction [47]. Therefore, it is clear that a key factor for the development and implementation of $2 \mathrm{G}$ biofuels is the reduction of production costs, which could be achieved by different mechanisms [43]:

- Reduction of feedstock costs, which include both the cost of the raw material itself and the costs associated to the supply chain. To address this challenge, it can be beneficial to analyze all supply chain operations, including harvesting, packing, transport, etc., in order to improve their efficiency in terms of both energy consumption and cost. Methodologies for biomass supply chain optimization and modeling, as well as simulation-based techniques, have been utilized to optimize the viability and efficiency of biomass feedstocks' supply chain management [48]. One feasible option in the short term would be an optimal site selection for a future plant, ensuring the availability of low-cost raw materials in a proximate zone.

- Reduction of capital costs. It can be achieved by scaling up the plant to a larger size (20-30\% reduction of capital cost), optimizing mass and energy integration, improving different process stages (e.g., use of surfactants as additives in SSF processes, improving detoxification processes and/or inhibitor removal, wastewater recycling, etc.) [49-51], and integrating 2G technology into an existing $1 \mathrm{G}$ facility. The latter could result in a $10-25 \%$ reduction of capital cost. More details about the integration of $1 \mathrm{G}$ and $2 \mathrm{G}$ technologies can be found in Section 5, which gives an overview of the different strategies for the integration of $1 \mathrm{G}$ and $2 \mathrm{G}$ ethanol plants.

- Reduction of operating and maintenance costs. Through this mechanism, a $25-50 \%$ reduction of capital costs could be obtained. This can be done by improving plant performance (e.g., increasing enzyme activity, integrated enzyme production, higher conversion efficiencies, etc.), reducing costs, and co-producing both bioethanol and high added-value products (e.g., chemicals, materials, food and feed products) within an efficient and integrated biorefinery concept. The latter is considered a promising pathway to reduce the production cost of bioethanol. Several studies about the development of integrated biorefinery concepts producing different valuable coproducts (e.g., xylitol, antioxidants, and furfural) could be found in the literature [52-54]. These studies use simulation tools (e.g., Aspen Plus, SuperPro Designer, etc.) with the aim of optimizing the processes from a technical and energetic point of view. Furthermore, those tools allow the necessary information to be obtained to analyze these biorefinery systems both from an economic and environmental point of view. It can be noted that the production costs depend on several factors, such as the plant capacity, the type of biomass used as feedstock, and the market value of the by-products obtained. More information about the coproduction of bio-products can be found in Section 6. 
Table 1. Worldwide 2G bioethanol plants. Sources: https://www.ieabioenergy.com/installations/; [43]

\begin{tabular}{|c|c|c|c|c|c|}
\hline Plant/Owner & Status & Location & $\begin{array}{l}\text { Capacity } \\
\mathrm{m}^{3} / \text { year }\end{array}$ & Raw Material & Comments \\
\hline Raizen/Cosan, Shell & Operational & Costa Pinto/Brazil & 40,000 & Sugar crop residue & $\begin{array}{l}\text { Production not yet at full capacity } \\
\text { TRL-8 }\end{array}$ \\
\hline Bioflex 1/GRanBio & Operational & $\begin{array}{l}\text { Sao Miguel, } \\
\text { Alagoas/Brazil }\end{array}$ & 60,000 & Sugarcane bagasse and straw & TRL-8 \\
\hline Liberty/Poet \& DSM & Operational & Emmetsburg, Iowa/USA & 76,000 & Agricultural residues & $\begin{array}{l}\text { Co-products: FT-liquids and biogas } \\
\text { TRL-8 }\end{array}$ \\
\hline $\begin{array}{l}\text { Abengoa Bioenergy Biomass of } \\
\text { Kansas/Abengoa }\end{array}$ & idle & Hugoton Kansas/USA & 95,000 & $\begin{array}{l}\text { Corn stover (main feedstock), wheat } \\
\text { straw, milo stubble, and switchgrass. }\end{array}$ & $\begin{array}{l}\text { Co-products: electricity ( } 21 \mathrm{MW}) \text {, lignin and animal feed. } \\
\text { TRL-8 }\end{array}$ \\
\hline Alpha/Beta Renewables & On hold & $\begin{array}{l}\text { Clinton, North } \\
\text { Carolina/USA }\end{array}$ & 76,000 & Energy grasses & TRL-8 \\
\hline DuPont Iowa plant & idle & Iowa, Nevada/USA & 105,000 & Corn stover & $\begin{array}{l}\text { In } 2018 \text { was sold to Verbio North America Corp, who is } \\
\text { planning to convert the plant to produce renewable } \\
\text { natural gas. } \\
\text { TRL-8 }\end{array}$ \\
\hline Crescentino/Versalis & Restart pending & Crescentino, Italy & 50,000 & $\begin{array}{l}\text { Wheat straw, rice straw, Arundo } \\
\text { donax, poplar }\end{array}$ & TRL-8 \\
\hline Podari/Clariant & Under Construction & Podari/Romania & 60,000 & Wheat and other cereal straw & $\begin{array}{l}\text { Clariant's sunliquid }{ }^{\circledR} \text { technology. } \\
\text { EU FP7 and BBI JU H2020 funding. } \\
\text { TRL } 8\end{array}$ \\
\hline Enviral & Planned & Slovakia & 62,000 & Lignocellulosic material & $\begin{array}{l}\text { Clariant's sunliquid }{ }^{\circledR} \text { technology. } \\
\text { TRL-9 }\end{array}$ \\
\hline AustroCel Hallein & Under Construction & Hallein/Austria & 38,000 & $\begin{array}{l}\text { Sulphite spent liquor from spruce } \\
\text { wood pulping }\end{array}$ & $\begin{array}{l}\text { Borregaard technology. } \\
\text { TRL-8 }\end{array}$ \\
\hline $\begin{array}{l}\text { Energochemica/Energochemica } \\
\text { SE }\end{array}$ & Upgrade planned & Strazske/Slovakia & 70,000 & $\begin{array}{l}\text { Agricultural residues and dedicated } \\
\text { crops }\end{array}$ & $\begin{array}{l}\text { Supported by the BBI JU project 'BIOSKOH' (Innovation } \\
\text { Stepping Stones for a novel European Second Generation } \\
\text { BioEconomy) } \\
\text { TRL-8 }\end{array}$ \\
\hline Domsjö Fabriker & Operational & Örnsköldsvik/Sweden & 24,000 & Sugars from pulping of lignocellulose & TRL-8 \\
\hline INA & Planned & Sisak/Croatia & 69,700 & Miscanthus and wheat straw & TRL-8 \\
\hline $\begin{array}{l}\text { Flagship integrated } \\
\text { biorefinery/Maabjerg Energy } \\
\text { Concept Consortiumn }\end{array}$ & On hold & Holstebro/Denmark & 63,400 & Plant dry matter, manure & $\begin{array}{l}\text { Co-products: biogas and lignin } \\
\text { TRL-8 }\end{array}$ \\
\hline
\end{tabular}


Table 1. Cont.

\begin{tabular}{|c|c|c|c|c|c|}
\hline Plant/Owner & Status & Location & $\begin{array}{l}\text { Capacity } \\
\mathrm{m}^{3} / \text { year }\end{array}$ & Raw Material & Comments \\
\hline Jedlicze Site/ORLEN Poludnie & Planned & Powiat/Poland & 31,700 & Wheat straw & $\begin{array}{l}\text { Clariant's sunliquid }{ }^{\circledR} \text { technology. } \\
\text { TRL-9 }\end{array}$ \\
\hline Cellulonix Follum/St1 & Planned & Ringerike/Norway & 50,700 & Sawdust & $\begin{array}{l}\text { Co-products: turpentine, wood vinasse, lignin, furfural, } \\
\text { biogas and } \mathrm{CO}_{2} \\
\text { TRL-8 }\end{array}$ \\
\hline Etanolix Hamina/St1 & Operational & Hamina/Finland & 1200 & $\begin{array}{l}\text { Bakery waste and process residues, } \\
\text { bread waste }\end{array}$ & TRL-9 \\
\hline Etanolix Vantaa/St1 & Operational & Vantaa/Finland & 1200 & $\begin{array}{l}\text { Bakery waste and process residues, } \\
\text { bread waste }\end{array}$ & TRL-9 \\
\hline Etanolix Lahti/St1 & Operational & Lahti/Finland & 1200 & $\begin{array}{l}\text { Food industry waste and process } \\
\text { residues, bread waste }\end{array}$ & TRL-9 \\
\hline Etanolix Jokionen/St1 & Operational & Jokionen/Finland & 8900 & $\begin{array}{l}\text { Bakery waste and process residues, } \\
\text { bread waste }\end{array}$ & TRL-9 \\
\hline Cellulonix Kajaani 2/St1 & Planned & Kajaani/Finland & 50,700 & Sawdust & $\begin{array}{l}\text { Co-products: turpentine, wood vinasse, lignin, furfural, } \\
\text { biogas and } \mathrm{CO}_{2} \\
\text { TRL-8 }\end{array}$ \\
\hline Cellulonix Pietarsaari/St1 & Planned & Pietarsaari/Finland & 50,700 & Sawdust & $\begin{array}{l}\text { Co-products: turpentine, wood vinasse, lignin, furfural, } \\
\text { biogas and } \mathrm{CO}_{2} \\
\text { TRL-8 }\end{array}$ \\
\hline Etanolix Gothenburg/St1 & Operational & Gothenburg/Sweden & 5000 & $\begin{array}{l}\text { Food waste and process residues, } \\
\text { bread waste }\end{array}$ & TRL-9 \\
\hline $\begin{array}{l}\text { Fuyang project } \\
\text { /Anhui Guozhen Group and } \\
\text { Chemtex Chemical Engineering }\end{array}$ & Planned & Fuyang/China & 63,000 & Wheat straw and corn stover & $\begin{array}{l}\text { Clariant's sunliquid }{ }^{\circledR} \text { technology. } \\
\text { TRL-8 }\end{array}$ \\
\hline Henan 1/Henan Tianguan Group & Operational & Zhenping, Henan/China & 12,700 & Wheat/corn stover & TRL-8 \\
\hline Henan 2/Henan Tianguan Group & idle & NanyangHenan/China & 38,000 & Lignocellulosic material & TRL-8 \\
\hline Longlive Bio-technology Co. Ltd. & idle & $\begin{array}{l}\text { Yucheng, } \\
\text { Shandong/China }\end{array}$ & 76,000 & Corn cob & TRL-8 \\
\hline Bargarh/Bharat Petroleum & Under construction & Bargarh/India & 30,000 & Rice straw & Praj Technology \\
\hline ABRPL refinery & Under Construction & Assam/India & 60,000 & Non-food grade bamboo & Formicobio Technology \\
\hline Bhatinda Plant/HPCL & Under construction & Bhatinda Plant/India & 40,000 & & DBT-ICT Technology \\
\hline Bina/Bharat Petroleum & Planned & Bina/India & 30,000 & Soya stalk and wheat straw & $\begin{array}{l}\text { DBT-ICT Technology } \\
\text { Investment decision not yet taken }\end{array}$ \\
\hline
\end{tabular}




\section{Advanced Bioethanol Production Processes}

Bioethanol can be produced from biomass by many advanced process pathways, such as the biochemical route (pretreatment, hydrolysis, and fermentation of lignocellulosic biomass), the thermo-catalytic route (biomass gasification and catalytic conversion of syngas), the hybrid route (biomass gasification and syngas fermentation), or the glycerol route (fermentation or catalytic conversion of glycerol generated during biodiesel production). Figure 3 shows a simplified scheme of these different routes.



Figure 3. Different bioethanol production pathways (adapted from [55]).

\subsection{Bioethanol Production from Lignocellulosic Biomass by the Biochemical Pathway}

As mentioned above, the development of the lignocellulosic ethanol market has been slower than expected in recent years due to the intensive capital costs, the prevision of a high technological risk, and the low oil prices. However, regulation to implement focused climate change mitigation strategies will give more weight to alternative technologies and secure the $2 \mathrm{G}$ biofuel industry $[56,57]$.

The basic procedure to obtain lignocellulose bioethanol consists in four steps, including a pretreatment (where the carbohydrates of the biomass become more accessible), an enzymatic hydrolysis (where sugars are generated from pretreated biomass by the addition of suitable enzymes), a fermentation (where alcohol is produced from C5 and C6 monomers), and finally, a distillation step (where a purified liquid fuel is produced) [45].

\subsubsection{Pretreatment of Lignocellulose}

The pretreatment stage is required to produce an extensive modification of lignocellulose, not only by modifying or removing lignin but also by solubilizing hemicellulose and reducing cellulose crystallinity, thus guarantying the better accessibility of hydrolytic enzymes to carbohydrates during the subsequent enzymatic hydrolysis [58]. The effectiveness of the pretreatment stage highly influences the overall process efficiency of the bioethanol production process. Some authors have calculated that up to $40 \%$ of the total cost of ethanol production is given by the pretreatment step. Many factors affect the profitability of pretreatment, including the energy spent during the process, the size and moisture content of the feedstock, the formation of by-products, etc. In the last decades, many physical, chemical, physicochemical, and biological pretreatment methods have been studied on a wide variety of feedstocks, either alone or under different combination strategies.

The mechanism for making carbohydrates more accessible to enzymes depends on the pretreatment applied and the feedstock nature. For instance, physical pretreatments alter the cellulose structure 
(mainly the crystallinity index and its degree of polymerization), reduce the particle size, and increase the specific surface area of cellulose. Grinding, chipping, or milling are common physical pretreatments, although their high energy consumption limits the economic viability of these methods [59]. However, the combination of different pretreatment technologies represents an interesting alternative with potential to increase energy savings and reduce costs [59]. Other physical pretreatments include electron beam, irradiation with microwave, and gamma rays. Special attention has recently been given to extrusion processes. This technology is based on the simultaneous heating, mixing, and shearing of lignocellulose into the extruder, promoting changes in biomass at the physical and chemical level (i.e., increasing the available cellulose surface area, reducing the cellulose crystallinity and degree of polymerization) $[60,61]$. One of the most attractive characteristics of extrusion is its versatility, since it offers different possibilities for combinations with chemicals or, more recently, with biological catalysts (bio-extrusion) [61].

Chemical pretreatments use different reagents, including acid, alkali, oxidizing agents, organic solvents, ionic liquids, and deep-eutectic solvents, to modify the structure and composition of lignocellulosic biomass. Acid catalysts (e.g., $\mathrm{H}_{2} \mathrm{SO}_{4}, \mathrm{H}_{3} \mathrm{PO}_{4}$, and organic acids, such as maleic, fumaric, or even acetic acid) promote hemicellulose hydrolysis and solubilization, with the dilute acid technology at high or low temperatures being very favorable for industrial applications [45]. On the other hand, alkaline reagents (e.g., $\mathrm{NH}_{4} \mathrm{OH}, \mathrm{NH}_{3}, \mathrm{NaOH}, \mathrm{KOH}$ and $\mathrm{Ca}(\mathrm{OH})_{2}$ ) increase cellulose digestibility mainly by lignin removal [62], causing generally less degradation compounds from sugars and lignin when compared to acid catalysts. In addition to acid and alkaline catalysts, organic solvents (e.g., ethylene glycol, methanol, acetone and ethanol) can also be applied to lignocellulose pretreatment. Co-solvent-enhanced lignocellulosic fraction (CELF) is a promising organosolv pretreatment technology that uses tetrahydrofurane for an effective lignin extraction [63]. Pretreatment with ionic liquids (ILs), salts that are liquids at relatively low temperatures, has been also considered as a promising technology for bioethanol production, even though their use at an industrial scale is limited by their high costs and the need of regeneration at very high ranges during the process [57,64]. Among them, 1-allyl-3-methylimidazolium chloride and 1-ethyl-3-methyl-imidazolium acetate are recognized as two of the most interesting ILs for lignocellulose pretreatment. These ILs promote solubilization of both lignin and sugars simultaneously at mild conditions, while generating a low concentration of inhibitory products. Bio-ionic liquids (e.g., tertiary amines) synthesized from lignin and hemicellulose have also showed good hydrolysability potential [65]. Deep eutectic solvents (DEPs), a class of eutectic mixtures of Lewis or Brønsted acids and bases, are new types of ILs formed from cationic and anionic species [66]. Among them, combinations between hydrogen-bond acceptors, such as guanidine hydrochloride or choline chloride, with hydrogen-bond donators, such as propylene glycol, ethylene glycol, or glycerin, have been used on different lignocellulosic biomasses, highlighting the high reactivity of extracted lignin [67].

Physico-chemical pretreatments, such as steam explosion, liquid hot water (LHW), sulfite pretreatment to overcome recalcitrance of lignocellulose (SPORL), ammonia fiber explosion/expansion (AFEX), extractive ammonia (EA), and supercritical pretreatment, have been widely used for lignocellulosic ethanol production [45]. One of the most widely used technologies at the industrial level is steam explosion. This pretreatment method has been applied to an extensive range of lignocellulosic feedstocks $[57,58]$. However, the material type highly influences the effectiveness of this process, and severe conditions (e.g., high temperatures and pressures) are usually required for an effective saccharification step. In this context, different biomass degradation products are released that may inhibit the hydrolytic enzymes and the fermentative microorganisms [68,69]. EA is another attractive physico-chemical pretreatment method that uses liquid ammonia to solubilize lignin polymer at elevated temperatures. The advantage of EA versus other ammonia-based methods, such as AFEX, is that offers the possibility of reducing the enzyme loading by $60 \%$ without influencing final enzymatic hydrolysis yields [70]. Moreover, the EA process generates a high purity lignin that can be further valorized within the biorefinery concept. 
Biological pretreatments use microorganisms and/or their enzymes to treat lignocellulosic biomass. Not only different fungi, such as white-rot basidiomycetes (e.g., Trametes versicolor, Ceriporiopsis subvermispora and Pleurotus ostreatus), but also endophytic fungi (e.g., Ulocladium sp. and Hormonema sp.) and some bacterial strains (e.g., Bacillus macerans, Cellulomonas cartae and Zymomonas mobilis) have been used for this purpose because of their ability to produce lignin-degrading enzymes (peroxidases and laccases), which increases saccharification yields [71,72]. The direct use of the enzymes secreted by these microorganisms during biological pretreatment is one of the most industrially viable choices since they can considerably shorten pretreatment times and do not require nutrient supplementation. Among them, laccases and laccase-mediator systems have been widely investigated to improve the enzymatic hydrolysis of lignocellulosic materials [73]. However, enzyme production cost is an important limitation and further investigations are needed towards implementing these lignin-degrading enzymes at a commercial scale.

To date, pretreatment technologies still present several drawbacks and greatly impact both saccharification and fermentation stages. As mentioned above, the harsh pretreatment conditions usually result in the degradation of biomass and consequently, certain inhibitory products are formed. Among them, compounds, such as formic acid, acetic acid, levulinic acid, 2-furaldehyde (furfural), 5-hydroxymethylfurfural (HMF), and phenolic compounds, may act as inhibitors during the downstream processing steps [45]. Different physical (e.g., evaporation and activated charcoal), chemical (e.g., overliming with $\mathrm{Ca}(\mathrm{OH})_{2}$ and ethyl acetate extraction), and biological (e.g., laccases) detoxification strategies have been studied to removed such degradation compounds [73]. In addition to these inhibitory compounds, lignin may also act as inhibitor of the enzymatic saccharification process as lignin encourages the non-specific absorption of hydrolytic enzymes to pretreated biomass, thus reducing saccharification yields. Here, delignification processes, such as alkaline, organosolv, or laccase treatment, can also be employed after some pretreatments processes to address the unproductive bindings.

\subsubsection{Enzymatic Hydrolysis}

After pretreatment, the carbohydrates contained in the pretreated biomass are depolymerized into soluble sugars by acid or enzymatic hydrolysis. Compared to acid hydrolysis, enzymatic hydrolysis shows certain advantages, such as the milder conditions under which it is performed, it does not use chemicals, and it requires less energy [74,75]. Enzymatic hydrolysis is influenced by several factors among which are not only the thermal stability of the enzymes used and the non-specific binding of the enzymes in the lignin but also the crystallinity and the degree of polymerization of the cellulose contained in the pretreated biomass as well as its hemicellulose and lignin content [76]. For that, a high number of enzymatic activities are involved during the enzymatic hydrolysis of lignocellulosic biomass, with cellulases being the most important. These enzymes depolymerize cellulose to glucose by a synergistic action of three activities, including endo 1,4-D-glucanase or E.C. 3.2.1.4 (endoglucanase), 1,4- $\beta$-D glucan cellobiohydrolase or E.C. 3.2.1.91c (exoglucanase or cellobiohydrolase), and $\beta$-glucosidase (EC 3.2.1.21). The majority of these activities are produced by the filamentous fungi Trichoderma reesei and Aspergillus niger, although some aerobic and anaerobic bacteria, termites, and some insects are also producers. Other accessory enzymes are also required for complete hydrolysis, such as hemicellulases and ligninases. Hemicellulases depolymerize hemicellulose to xylose, arabinose, mannose, and galactose, including xylanases (e.g., endoxylanases or E.C. 3.2.1.8 and $\beta$-xylosidases or E.C. 3.2.1.37), mannanases (e.g., endomannanases or E.C. 3.2.1.78 and $\beta$-mannosidases or E.C. 3.2.1.25), debranching enzymes (e.g., $\alpha$-L-arabinofuranosidases or E.C. 3.2.1.55 and $\alpha$-glucuronosidases or E.C. 3.2.1.131), and esterases (e.g., acetyl xylan esterases or E.C. 3.1.1.72 and ferulic esterases or E.C. 3.2.1.73). On the other hand, ligninases, including ligninolytic peroxidases, laccases, oxidases that generate extracellular $\mathrm{H}_{2} \mathrm{O}_{2}$, and reductases, are responsible for the degradation of the lignin polymer [42,76]. Special attention has been given to the application of laccases (EC 1.10.3.2) in the last years [77]. The capacity of these enzymes to oxidize phenols allows an increase of 
saccharification yields through delignification and detoxification processes. Moreover, laccases can increase their effectiveness towards modifying and/or partially removing the non-phenolic lignin units when combined with low-molecular-weight compounds (known as mediators), increasing the final hydrolysis yields of different pretreated materials.

The enzymatic mixtures and the enzyme production process still need to be optimized to increase the hydrolysis yields and consequently, the final ethanol concentrations. Here, the use of low-cost substrates and/or novel enzymatic activities such as the non-hydrolytic enzymes polysaccharide monooxygenases (LPMOs) and the non-catalytic proteins swollenins and expansins, may contribute to reaching that goal. LPMOs (EC 1.14.99.53-56) can oxidize the crystalline regions of cellulose, making it more susceptible to cellulases, although more detailed studies are needed to really evaluate their efficacy in enzymatic hydrolysis [78]. As in the case of LPMOs, swollenins and expansins also seem to be capable of attacking the crystalline part of the cellulose [79]. In addition, several studies have focused on screening and/or engineering different enzyme-producing microorganisms to increase the catalytic efficiency of hydrolytic enzymes [76]. As a result of all these strategies, a multitude of enzymatic cocktails have been developed by some industries, such as Acellerase ${ }^{\mathrm{TM}}$ 1000, Spezyme ${ }^{\circledR}$ CP, Acellerase ${ }^{\mathrm{TM}}$ DUET, and Acellerase ${ }^{\mathrm{TM}} 1500$ from Genencor, and Novozyme 188, Celluclast ${ }^{\circledR} 1.5 \mathrm{~L}$, Cellic ${ }^{\circledR}$ CTec2, and Cellic ${ }^{\circledR}$ CTec3 from Novozymes [42]. Some of them have already been used by different companies in enzymatic hydrolysis processes scaled up to the industrial level, such as Abengoa, Raizen, DuPont, POET, Beta Renewables, and GranBio.

\subsubsection{Fermentation}

Several yeast, bacterial, and/or fungal strains have been used as fermentative microorganisms for the biochemical conversion of sugars to ethanol. At the industrial level, the yeast $S$. cerevisiae is the most commonly used microorganism for bioethanol production [45]. S. cerevisiae is capable of converting all kinds of hexoses into ethanol with high conversion yields (close to the theoretical). Moreover, it is especially robust towards inhibitory products and ethanol, and has a remarkable tolerance against osmotic stress. The major handicap of this yeast is, however, its inability to metabolize pentose sugars (xylose is second after glucose in lignocellulosic biomass). This has led to extensive research and development of novel fermentative microorganisms with the capacity to convert both hexoses and pentoses into ethanol.

Different metabolic strategies have been addressed to develop efficient engineered xylosefermenting S. cerevisiae strains. One of them is based on the introduction in S. cerevisiae of different metabolic pathways for xylose assimilation, such as the oxidoreductive pathway, which involves xylose reductase (XR) and xylitol dehydrogenase (XDH) enzymes, and the xylose isomerase (XI) pathway [80]. The first one consists of the introduction of the XYL1 and XYL2 genes of xylose-fermenting yeasts (mainly from Scheffersomyces stipitis), which encode for XR and XDH, respectively [81,82]. The second one is based on the introduction of the gene encoding for XI present in bacteria and some fungi [83]. Both strategies must be accompanied by overexpression of the XKS1 gene encoding for endogenous xylulose kinase (XK) [84], an enzyme that phosphorylates xylulose, the product generated in both pathways. In addition, an improvement of xylose consumption by $S$. cerevisiae has been achieved through the overexpression of different genes encoding for membrane transporters with a major affinity for xylose, such as Sut1 form S. stipitis, Trxlt1 from Trichoderma reseei, and Gxf1 from Candida intermedia [85].

With the aim of designing better engineering strategies, other native xylose-fermenting yeasts, such as Candida tropicalis, Candida shehatae, Pachysolen tannophilus, S. stipitis, and Spathaspora passalidarum are under investigation to clarify crucial physiological mechanisms for optimal pentose conversion to ethanol [3]. However, these species present low ethanol yields, poor tolerance to ethanol and inhibitors, and a great sensitivity to $\mathrm{pH}$ changes, which makes their application on an industrial scale difficult. Some filamentous fungi (e.g., Fusarium oxysporum, Mucor circinelloides and Rhizopus oryzae) have also exhibited xylose fermentation $[86,87]$. These strains are in general more tolerant than xylose-fermenting yeasts to lignocellulose-derived inhibitors, but the industry does not consider their 
use due to their lower conversion rates. Ethanologenic xylose-fermenting bacteria, such as Escherichia coli and Klebsiella oxytoca, are also attractive xylose fermenters and show better growth rates than xylose-fermenting yeasts [45]. This allows an improvement of the volumetric productivities and a reduction of the overall process time, although they usually show lower robustness. Xylose can be also utilized by engineered $Z$. mobilis after introducing it to the xylose metabolizing pathway from $E$. coli [88].

Together with xylose-fermenting microorganisms, the cost-competitive lignocellulosic ethanol production also demands robust fermenting microorganisms with high tolerance to inhibitory compounds, ethanol and/or mechanical and osmotic stress, and relatively high temperatures. Different non-Saccharomyces species, such as Zygosaccharomyces bailii, Wickerhamomyces anomalus, Pichia kudriavzevii, and Candida stellate, have shown natural tolerance to high concentrations of inhibitors, including acetic acid or furans [45]. Moreover, several strategies to develop robust S. cerevisiae strains with enhanced tolerance to inhibitory compounds have been reported. For instance, metabolic engineering, such as the overexpression of genes encoding enzymes that confer resistance to specific inhibitors (e.g., furfural), has improved the tolerance of S. cerevisiae to these compounds [89]. In addition, evolutionary engineering is an effective method to obtain new $S$. cerevisiae strains with improved robustness, leading to increased detoxification rates of furfural and HMF, shorter lag phases, increased sugar consumption rates, and higher ethanol yields in the subsequent fermentation step [90]. Regarding high ethanol tolerance, similar to S. cerevisiae, species, such as Dekkera bruxellensis, P. kudriavzevii, Schizosaccharomyces pombe, Torulaspora delbrueckii, and W. anomalus, have also shown high ethanol tolerance levels [91]. S. cerevisiae also shows high tolerance to osmotic pressures, a process that can lead to water loss and cell shrinking of microorganisms. Candida bombi and Starmerella bombicola have shown even higher osmotolerance than S. cerevisiae [91], and Zygosaccharomyces rouxii is one of the most halotolerant and osmotolerant yeast species [92]. Finally, the use of thermotolerant yeasts for lignocellulosic ethanol production is advantageous under SSF configurations due to the differences in the optimal conditions for the enzymatic hydrolysis and fermentation steps. Some thermotolerant yeast strains, including S. cerevisiae, Kluyveromyces marxianus, and Fabospora fragilis, can produce ethanol at temperatures around $40-45^{\circ} \mathrm{C}$ [45]. Ogataea polymorpha is a yeast species able to grow at temperatures higher than $50^{\circ} \mathrm{C}$. This species can also ferment xylose and cellobiose into ethanol, thus representing an interesting choice for SSF processes. Ethanologenic thermophilic bacteria from Thermoanaerobacterium, Thermoanaerobacter, Clostridium, or Caldanaerobacter genera and the species Caloramator boliviensis have also been reported $[93,94]$.

After enzymatic hydrolysis, the resulting sugars can be converted into a wide range of fermentation-based products, including bioethanol. Both enzymatic hydrolysis and fermentation can be performed under different process strategies and at different integration levels. The main configurations strategies are separate hydrolysis and fermentation (SHF), simultaneous saccharification and fermentation (SSF), and consolidated bioprocessing (CBP), which can be run under different operational modes, including batch, fed-batch, and continuous mode. Furthermore, an extra prehydrolysis step (mainly in the SSF configuration strategy) or the use of membrane bioreactors or immobilized cells has also been investigated for lignocellulosic bioethanol production [45].

The separate hydrolysis and fermentation (SHF) configuration has traditionally been used for bioethanol production. In this case, enzymatic hydrolysis and fermentation are carried out separately, which is expensive and time-consuming. Moreover, product inhibition of cellulase activity may result from sugar accumulation [95], although this problem can be solved in situ by removing released sugars by dialysis. The main advantage of this configuration is that both enzymatic hydrolysis and fermentation can operate in their optimal $\mathrm{pH}$ and temperature conditions.

The simultaneous saccharification and fermentation (SSF) configuration combines the enzymatic hydrolysis and fermentation stages in a single reactor, reducing costs and process time. In this strategy, the fermentative microorganisms can consume the released glucose right after being hydrolyzed by enzymes $[96,97]$. In general, ethanol production under the SSF configuration is higher than that of SHF. 
This is mainly due to the presence of a low sugar concentration during the process, which does not inhibit cellulase activities [98]. However, this configuration requires compatible process conditions for both enzymatic hydrolysis and fermentation (i.e., temperature and $\mathrm{pH}$ ). In general, the choice between SHF and SSF strategies depends on several factors, such as the pretreatment method used, the type of biomass, the solid loadings and the hydrolytic enzymes, and the fermentative microorganism. SSF processes can also be called simultaneous saccharification and co-fermentation (SSCF) when using pentose-rich feedstocks and pentose-fermenting microorganisms. This strategy offers great potential for increasing ethanol production yields since both glucose and xylose can be used as substrate [99].

The consolidated bioprocessing (CBP) configuration includes enzyme production, enzymatic hydrolysis, and fermentation in a single stage $[100,101]$. The most studied microorganisms for CBP processes are different bacteria species from the Clostridium genus (e.g., Clostridium thermocellum or Clostridium phytofermentans) [102-104]. As an alternative, genetically engineered bacteria, yeasts, and fungi have also been investigated for ethanol production under the CBP configuration [105]. CBP is considered as the most promising configuration for bioethanol production from lignocellulose. However, the majority of CBP organisms developed so far have limited applicability when used with real lignocellulosic biomass due to their low tolerance to ethanol or their limited growth among other reasons. Therefore, extensive research is still needed to further develop this option.

\subsection{Other Processes for Advanced Ethanol Production}

Lignocellulosic bioethanol is mainly obtained by the biochemical route using wood, herbaceous crops, and residues as feedstock. However, during the last decades, several researchers have focused their work on the development of advanced processes based on the utilization of novel raw materials (such as municipal solid waste, industrial residues, algae, and also syngas or bio-based glycerol), and also on new thermochemical or hybrid routes that can overcome some of the major drawbacks of the biochemical route for the production of $1 \mathrm{G}$ and $2 \mathrm{G}$ bioethanol.

\subsubsection{Novel Raw Materials}

Apart from lignocellulosic biomass, such as woody and herbaceous crops and agricultural and forest residues, other residues, such as municipal solid waste (MSWs) and industrial residues, have been evaluated as feedstock for bioethanol production. These residues are considered a promising alternative for food crops in the production of $2 \mathrm{G}$ biofuels $[55,106,107]$. Nevertheless, it should be taken into account that many of these residues already have valuable applications as fertilizer, fodder, and soil conditioner, or are used as raw materials for several products, such as recycled paper, medium-density fiberboard, and particleboard [106]. Therefore, these alternative uses should be considered when evaluating the availability of these biomass residues and wastes.

Municipal solid waste includes food waste, skins, shells, and other compounds with a certain proportion of cellulose, hemicelluloses, and lignin. It also includes a vegetable fraction from pruning and gardening remains. MSWs are normally used for the production of compost and energy by direct combustion or natural anaerobic digestion generating biogas [107]. Nonetheless, a growing interest in the conversion of MSWs into liquid biofuels has been observed in the last decade due to its low cost, high production potential, and the possibility of offering a sustainable solution to its disposal $[106,108]$. At the industrial scale, there are several facilities that convert the organic fraction of MSWs on bioethanol based on the thermochemical routes: Enerkem (Montréal, QC, Canada), Fulcrum BioEnergy (Pleasanton, CA, USA), and Solena Fuels (Thurrock, UK). On the other hand, bioethanol from MSWs can also be produced by the biochemical route, consisting in pretreatment, hydrolysis, and fermentation $[106,109]$. There are also some facilities at the industrial scale based on this route, such as Fiberight (Hampden, ME, USA) and Perseo BioRefinery (L'Alcúdia, Spain).

Regarding industrial lignocellulosic residues, they are generated as waste and by-products in several agro-food industries, such as sugar industry (generating molasses and bagasse), brewing and malting industry (bagasse, waste grains), wine industry (grape seeds, stems, pomace, lees, vinasse), 
and olive oil industry (pomace, vegetable water, exhausted olive pomace cake) among others [110,111]. Pulp and paper industry also generates different residues that can be used as feedstock in the production of biofuels. Moreover, this industry presents the logistics and infrastructure that are required to handle lignocellulosic biomass, representing a promising option for integrated biorefineries where apart from producing pulp and paper, different waste and by-products can be valorized [112,113]. In this context, Branco et al. [112] reviewed the feasibility of producing ethanol from Kraft pulp, spent sulfite liquor, and pulp and paper sludge. Thus, kraft pulping can be considered as a pretreatment in the biochemical route, using the resulting solid fraction (kraf pulp) for fermentable sugar production. The resulting liquid fraction (black liquor) has been reported to be unsuitable for bioethanol production due to its low sugar content. On the contrary, in sulfite pulping, the spent liquor contains hexose and pentose sugars from the acid hydrolysis of wood polysaccharides, apart from solubilized lignin and degradation products, such as furfural and HMF. Thus, spent sulfite liquor has been evaluated for the production of ethanol since the 1980s for several authors [112]. Other authors have also evaluated the possibility of extracting a fraction rich in hemicelluloses prior to pulping that can be used for the production of bioethanol [114-116]. However, the utilization of C5 for bioethanol is still a challenge. Last but not least, pulp and paper mill sludge (PPMS) should be considered. It represents the main organic waste resulting from wastewater treatment, including primary sludge, secondary sludge, and de-inking sludge [112]. PPMS is thickened and dewatered and landfilled or incinerated for combined heat and power generation. It can also be used in biocomposites of wood and plastic, cement, or asphalt. Nonetheless, PPMS has also been used to produce liquid biofuels (through acetone-butanol-ethanol fermentation), hydrogen, cellulose, biogas (from anaerobic digestion), and bio-oil (from pyrolysis). Regarding bioethanol production, PPMS contains short fibers that are easily hydrolyzed by enzymes into fermentable sugars, requiring no pretreatment. The major problem is the high content in ash, mainly $\mathrm{CaCO}_{3}$, which absorbs to the enzymes and increases the $\mathrm{pH}$, reducing the yields of enzymatic hydrolysis. Therefore, a de-ashing step is necessary to remove $\mathrm{CaCO}_{3}$, usually achieved using acids, with its associated environmental impact. Hence, the development of new de-ashing techniques with low environmental impact is still required to achieve higher hydrolysis and fermentation yields [112].

The potential of algal biomass for the production of biofuels and bio-based products is also under intensive research. Microalgae are extraordinarily efficient photosynthetic microorganisms with high productivity and simple growing requirements that can be used as feedstock for carbohydrates, lipids, and proteins [106]. Conversely, macroalgae have a low concentration of lipids and primarily contain carbohydrate and proteins [117]. There are several pathways for the conversion of algal biomass into biofuels and biomaterials, but the three main conversion processes are oil transesterification (biodiesel), ethanol fermentation (third-generation (3G) bioethanol), and anaerobic digestion (biogas) $[106,118]$. Regarding bioethanol production, although algae contain small amounts of hemicelluloses and negligible lignin, a pretreatment is still needed to make the sugars accessible. The most applied pretreatments are acid and alkali pretreatment because they are less energy intensive and provide efficient extraction of the unwanted materials [118]. Nevertheless, some other polymers can be present in the algal biomass, such as fucoidan, alginate, and mannitol, making additional processing necessary before separate hydrolysis and fermentation. SSF is also possible if potential microbial strains able to produce amylase enzyme and to induce saccharification are used [119]. Despite the benefits of using algal biomass as a feedstock (such as the ability to accumulate lipids and sugars, reduced cultivation time, and no or minimal fresh water requirements for growing), intensive research is still needed to overcome its limitations and uncertainties regarding its implementation at a commercial scale [120,121].

Finally, it should be mentioned that both syngas and bio-based glycerol represent alternate promising feedstocks for bioethanol production [55]. Syngas can be obtained by gasification of a wide range of sources and allows the conversion of the whole biomass, including lignin. On the other hand, the production of biodiesel generates large quantities of bio-based glycerol. Both syngas and glycerol can be biologically and catalytically converted into bioethanol, as will be discussed in the following section. 


\subsubsection{Alternative Processes}

As discussed above in Section 4.1, the biochemical route is the most implemented pathway for bioethanol production. However, it is worthwhile reviewing the other routes.

\section{(1) Thermo-catalytic route}

The thermo-catalytic route is based on gasification of biomass to obtain syngas, which is further catalytically converted to bioethanol. Gasification is a thermochemical process in which a carbonaceous biomass (solid or liquid) reacts with a gasifying agent (air, oxygen, and/or steam), producing a gas called synthesis gas or syngas. It involves many overlapping sub-processes, such as drying, pyrolysis, and partial oxidation, comprising complicated combinations of numerous reactions [122].

Syngas is a mixture of $\mathrm{CO}, \mathrm{H}_{2}, \mathrm{CO}_{2}$, and $\mathrm{CH}_{4}$ as primary components, although small amounts of tars, $\mathrm{H}_{2} \mathrm{O}, \mathrm{H}_{2} \mathrm{~S}, \mathrm{NH}_{3}$, and other species can also be found, depending on the type of feedstock, gasification system, and operating conditions $[117,122,123]$. The optimal mixture for biofuel production contains mainly $\mathrm{CO}$ and $\mathrm{H}_{2}$, and the presence of other hydrocarbons and inert components should be kept as low as possible. To obtain a good performance of the resulting gas mixture (high content of $\mathrm{H}_{2}$ and $\mathrm{CO}$ ), a minimum temperature of $650-700{ }^{\circ} \mathrm{C}$ is necessary. On the other hand, to avoid technical problems due to the fusion and agglomeration of ashes, a maximum temperature is imposed, generally 950-1150 ${ }^{\circ} \mathrm{C}$ [123]. The required heat can be inherently produced by exothermic combustion reactions or can be supplied from outside sources [122].

Syngas can be used as raw material not only for power generation but also for liquid biofuels (methanol, ethanol, dimethylether (DME), and Fischer-Tropsch diesel), gaseous biofuels (hydrogen and synthetic natural gas), and chemicals synthesis. Worldwide, $50 \%$ of the produced syngas is used for ammonia synthesis, 25\% for bio-hydrogen generation, and the rest for bio-methanol production, Fischer-Tropsch synthesis, and other processes [124]. Before its utilization, biomass-derived syngas should be cleaned in most applications, in order to remove contaminants, such as condensable hydrocarbons (tars), particulate matter, alkaline metals $(\mathrm{Na}, \mathrm{K})$, nitrogen $\left(\mathrm{NH}_{3}, \mathrm{HCN}\right)$, sulfur $\left(\mathrm{H}_{2} \mathrm{~S}\right.$, $\left.\mathrm{COS}, \mathrm{CS}_{2}\right)$, halides $(\mathrm{HCl}, \mathrm{HBr}, \mathrm{HF})$, and trace elements. These contaminants are generated due to impurities in biomass feedstocks and partial gasification and they can induce problems in the gasifier (corrosion, clogging, and catalyst deactivation) and render syngas unsuitable for some applications. Details about syngas cleaning technologies can be found elsewhere [122].

Bioethanol can be catalytically synthesized from biomass-derived syngas via three different pathways (Figure 4): (1) direct conversion; (2) methanol homologation, and (3) the ENSOL process $[122,123,125]$. Direct conversion of syngas to bioethanol is based on the selective hydrogenation of carbon monoxide at the surface of the Rh-based catalyst (Equation (1)). A low temperature $\left(230-300^{\circ} \mathrm{C}\right.$ ) and high pressure (up to 100 bar) are favorable for this synthesis (Molino et al., 2018).

$$
2 \mathrm{CO}+4 \mathrm{H}_{2} \rightarrow \mathrm{C}_{2} \mathrm{H}_{5} \mathrm{OH}+\mathrm{H}_{2} \mathrm{O} \quad\left(\Delta \mathrm{H}_{298}=-253.6 \mathrm{~kJ} \mathrm{~mol}^{-1}\right) .
$$

The second pathway is carried out through methanol synthesis (Equation (2)) followed by methanol homologation (Equation (3)), which involves reductive carbonylation over the surface of $\mathrm{Cu} / \mathrm{Co}-$ based catalyst:

$$
\begin{gathered}
\mathrm{CO}+2 \mathrm{H}_{2} \leftrightarrow \mathrm{CH}_{3} \mathrm{OH} \quad\left(\Delta \mathrm{H}_{298}=-90.6 \mathrm{~kJ} \mathrm{~mol}^{-1}\right) \\
\mathrm{CH}_{3} \mathrm{OH}+\mathrm{CO}+2 \mathrm{H}_{2} \leftrightarrow \mathrm{C}_{2} \mathrm{H}_{5} \mathrm{OH}+\mathrm{H}_{2} \mathrm{O} \quad\left(\Delta \mathrm{H}_{298}=-165.1 \mathrm{~kJ} \mathrm{~mol}^{-1}\right) .
\end{gathered}
$$

The ENSOL process consists of the synthesis of methanol from syngas (Equation (4)), acetic acid generation through methanol carbonylation (Equation (5)), and ethanol synthesis via hydrogenation of acetic acid (Equation (6)). This approach needs a different catalyst for each step, making it expensive and complex:

$$
\mathrm{CO}+2 \mathrm{H}_{2} \leftrightarrow \mathrm{CH}_{3} \mathrm{OH} \quad\left(\Delta \mathrm{H}_{298}=-90.6 \mathrm{~kJ} \mathrm{~mol}^{-1}\right),
$$




$$
\begin{aligned}
\mathrm{CH}_{3} \mathrm{OH}+\mathrm{CO} & \rightarrow \mathrm{CH}_{3} \mathrm{COOH} \quad\left(\Delta \mathrm{H}_{298}=-123.3 \mathrm{~kJ} \mathrm{~mol}^{-1}\right), \\
\mathrm{CH}_{3} \mathrm{COOH}+2 \mathrm{H}_{2} & \rightarrow \mathrm{C}_{2} \mathrm{H}_{5} \mathrm{OH}+\mathrm{H}_{2} \mathrm{O} \quad\left(\Delta \mathrm{H}_{298}=-41.7 \mathrm{~kJ} \mathrm{~mol}^{-1}\right) .
\end{aligned}
$$

Several thermodynamically favored side reactions like methanation and kinetically favored chain growth reactions reduce the bioethanol yield and selectivity. Controlling the operational conditions and the selection of an effective catalyst, both selectivity and yield could be increased [122,126]. Therefore, numerous research works on different catalysts, including both homogeneous and heterogeneous catalysts, have been carried out for the different bioethanol synthesis pathways $[55,122]$. Furthermore, a high $\mathrm{H}_{2} /\left(\mathrm{CO}+\mathrm{CO}_{2}\right)$ ratio and low $\mathrm{CO}_{2} / \mathrm{CO}$ ratio also contribute to increasing bioethanol yields [122,123]. Here, the syngas composition should be controlled not only by gas cleaning but also by selecting an adequate feedstock.

\section{(2) Hybrid route}

The hybrid route involves the gasification of the biomass and the fermentation of syngas. Hence, the first step (gasification) is similar to that described in the thermo-catalytic route. Once syngas is obtained, it is cleaned and cooled before being fed into a bioreactor where autotrophic microbes convert syngas into bioethanol and other alcohols and organic acids. Syngas fermentation presents some advantages over chemo-catalytic production of bioethanol, such as: (1) higher product specificity; (2) lower energy cost, since fermentation occurs at near-ambient temperatures and pressures; (3) most microorganisms are tolerant to trace amounts of some contaminants present in syngas, such as sulfur and chloride compounds, which easily poison metal catalysts; and (4) the final products are not influenced by the $\mathrm{H}_{2} / \mathrm{CO}$ ratio since both $\mathrm{CO}$ and $\mathrm{H}_{2} / \mathrm{CO}_{2}$ mixtures can be simultaneously fermented $[108,117]$. However, its main technical challenge is the low solubility of the synthesis gas in water, which limits the mass transfer. Furthermore, fermentation also needs a long residence time, due to the slow reactions and slow growth of the microorganisms on the gaseous substrate (instead of sugar substrates). Thus, the conversion yields depend on the reactor design, selected microorganism, composition of the specific gas mixture fed (gas partial pressure), and cultivation conditions, such as temperature, pressure, medium components, and reducing agent $[55,117]$.

The microorganisms used for bioethanol production from syngas are acetogenic bacteria from the Clostridium family (first and foremost Clostridium ljungdahlii and Clostridium autoethanogenum), which can grow chemolithotrophically (using inorganic reduced compounds as the energy source) under anaerobic conditions and produce ethanol and butanol, along with butyrate and acetate, from $\mathrm{CO}, \mathrm{CO}_{2}, \mathrm{H}_{2}$, formate, and methanol $[55,117]$. Acetogens use the acetyl-CoA or Wood-Ljungdahl pathway to metabolize single carbon source compounds to (1) synthesize acetyl moiety of acetyl-CoA from $\mathrm{CO}_{2}$, (2) assimilate $\mathrm{CO}_{2}$ to cell carbon, and (3) conserve energy by the reduction of $\mathrm{CO}$, and/or $\mathrm{CO}_{2}$ and $\mathrm{H}_{2}$ to acetate [117]. The acetyl-CoA intermediate can then be converted to cell mass and/or different metabolites, such as ethanol, acetate, butyrate, or butanol, among others, depending on the available enzymes $[108,117]$. Thus, acetyl-CoA can be converted to ethanol via aldehyde/alcohol dehydrogenase (solventogenesis pathway). Moreover, bioethanol can also be produced from acetate via aldehyde:ferredoxin oxidoreductase [108]. The final product mixture is determined by the chosen microorganism and the operating conditions [55].

\section{(3) Glycerol route}

The increasing production of biodiesel, which can be produced from different types of lignocellulosic biomass, involves the generation of large volumes of glycerol: approximately $10-20 \%$ of the total volume of biodiesel produced [127]. Consequently, great attention has been directed to the conversion of glycerol into high-value and useful products, enhancing the economic viability of biodiesel production $[127,128]$. This bio-based glycerol has low quality, requiring purification before its use in food, pharmaceutical, cosmetics, and other personal care industries, making the process not economically favorable [128]. However, raw glycerol or partially treated raw glycerol can 
be used as feedstock for bioethanol production, among other applications [55,127,129]. Bioethanol can be produced from glycerol via chemical or biological routes. Thus, glycerol can be catalytically hydrogenated, although selective catalysts for ethanol production are still under investigation [55,130]. On the contrary, ethanol fermentation is far more developed [55,127]. Different microorganisms have been used to convert glycerol to ethanol at the laboratory scale, such as E. coli, Ogataeo polymorpha, and different species of Klebsiella, Enterobacter, Citrobacter, and Clostridium [127,131]. The fermentation of glycerol by these microorganisms usually produces other products along with bioethanol, such as 1,3-propanediol, acetate, butanol, formate, hydrogen, etc. The production of the target products can be maximized by modifying process conditions and/or microorganism selection [131].

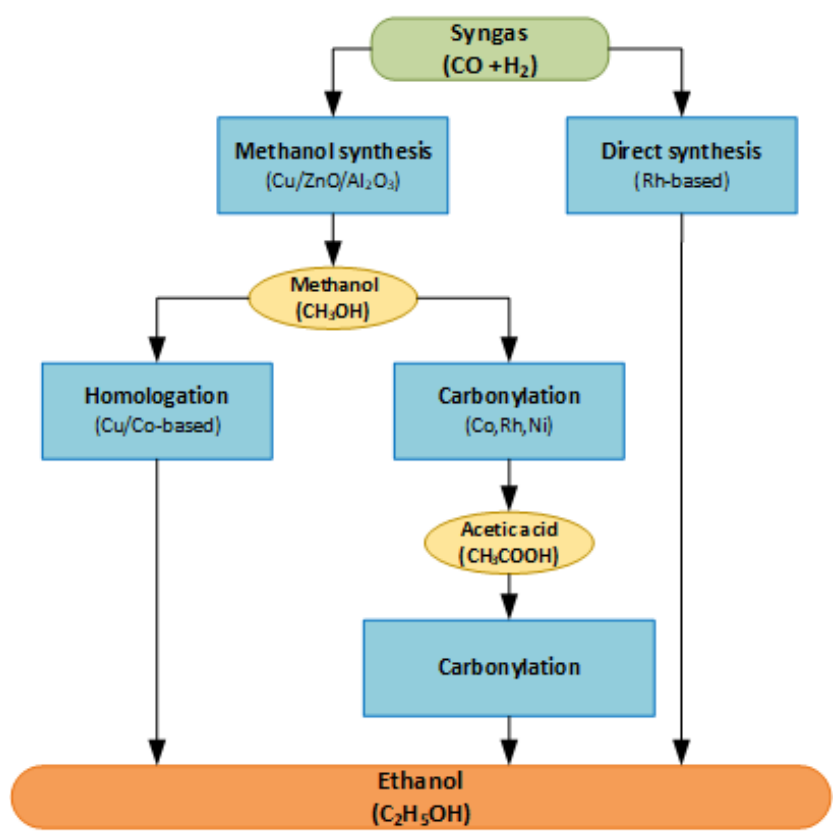

Figure 4. Different thermochemical bioethanol production pathways (adapted from [122]).

\section{Integration Strategies for $1 \mathrm{G}$ and $2 \mathrm{G}$ Technologies}

As commented above, in recent years, it has become clear that there is a necessity for a transition from first-generation (1G) to second-generation (2G) bioethanol production. Since $2 \mathrm{G}$ bioethanol production still presents uncertainties regarding its economic viability, the integration of $2 \mathrm{G}$ technology into an existing $1 \mathrm{G}$ facility could be an excellent strategy to ease the transition from $1 \mathrm{G}$ to $2 \mathrm{G}$ biofuels. Furthermore, the integration of $1 \mathrm{G}$ and $2 \mathrm{G}$ ethanol technologies could result in synergies and cost savings, supporting the establishment of $2 \mathrm{G}$ ethanol production. The synergies could result from using the lignocellulosic parts of the sugar and starch crops, such as wheat bran, bagasse, leaves, etc.; sharing the purification areas; adapting the sugar content of the fermentation by mixing the mash; sharing the general infrastructure of the plant; or using lignin as a renewable fuel for the energy supply [132]. Different options for the integration of $1 \mathrm{G}$ and $2 \mathrm{G}$ ethanol plants can be defined as follows:

\subsection{Co-Locating}

Co-locating, placing a $2 \mathrm{G}$ facility next to an existing $1 \mathrm{G}$ plant, is the easiest implementation strategy. This strategy allows the $2 \mathrm{G}$ bioethanol plant to take advantage of the existing product distribution as well as the feedstock supply and storage systems, and to share utilities, which could lead to a decrease in $2 \mathrm{G}$ bioethanol production cost and investor risks [46]. Nowadays, there are several bioethanol plants based on this type of strategy in Brazil and the USA. For example, the Raizen facility in Piracicaba, Sao Paulo, Brazil, was installed alongside the Costa Pinto sugar/ethanol plant and uses bagasse and sugarcane residues as raw material. This facility started to be constructed in 2014 and has a bioethanol 
production of about 31,600 tons/year. It required an investment of approximately $56 \mathrm{M€}[46,133]$. The Raizen facility is still in operation and has the lowest minimum $2 \mathrm{G}$ ethanol selling price ( $\$ 0.57$ per L) compared to other 2G ethanol plants, such as Abengoa's plant in Hugoton, USA (\$ 1.20 per L; currently non-operational) or Dupont's plant in Nevada (\$0.87 per L; currently non-operational). This low price is due to the access to low-cost feedstock, including sugarcane straw and sugarcane bagasse [134].

In the USA, POET-DSM biorefinery (Project Liberty) was built next to the existing 1G corn ethanol facility in Emmetsburg, Iowa, sharing energy, land, feedstock supply system, and personnel. This biorefinery uses post-harvest corn stover as feedstock (cobs, leaves, husks, and upper stalks) and produces approximately 75,000 tons/year of ethanol. Its development required an investment of around $100 \mathrm{M} \$$ from the U.S. Department of Energy. This facility started to operate in 2014 and is still in operation nowadays. Although the minimum cellulosic ethanol selling price ( $\$ 0.87$ per $\mathrm{L}$ ) is higher than the previous case, it is expected that this facility increases Iowa's economic output by $\$ 24.4$ billion and generates more than 13,500 jobs. Moreover, POET has suggested the implementation of this strategy at the other 27 corn ethanol plants in North America $[135,136]$.

\subsection{Retrofitting}

Retrofitting of a $1 \mathrm{G}$ ethanol facility with $2 \mathrm{G}$ technology consists of partially replacing a factory or installation with state-of-the-art equipment, so that unutilized by-products or parts of the feedstock can be used to produce $2 \mathrm{G}$ bioethanol together with $1 \mathrm{G}$ bioethanol $[46,132]$. Retrofitting is considered a more attractive alternative to promote the transition from $1 G$ to $2 G$ ethanol instead of building a brand-new plant with full advance technology. Retrofitting often means lower capital expenditure (CAPEX), shorter lead times, faster implementation, less production time losses, and lower risks than building a completely new $2 \mathrm{G}$ ethanol facility [132].

Retrofitting of $1 \mathrm{G}$ ethanol facilities can be made through the integration of the $2 \mathrm{G}$ process at different stages of the $1 \mathrm{G}$ processing plant, such as the fermentation or purification process step. Therefore, different processing schemes for the retrofitting of an existing $1 \mathrm{G}$ facility can be developed. These schemes also differ depending on the type of feedstock used in the process (sugar or starch based) and the co-products obtained. Figures 5 and 6 show different possible configurations.



Figure 5. Possible configurations for the retrofitting of a starch-based $1 \mathrm{G}$ facility. 


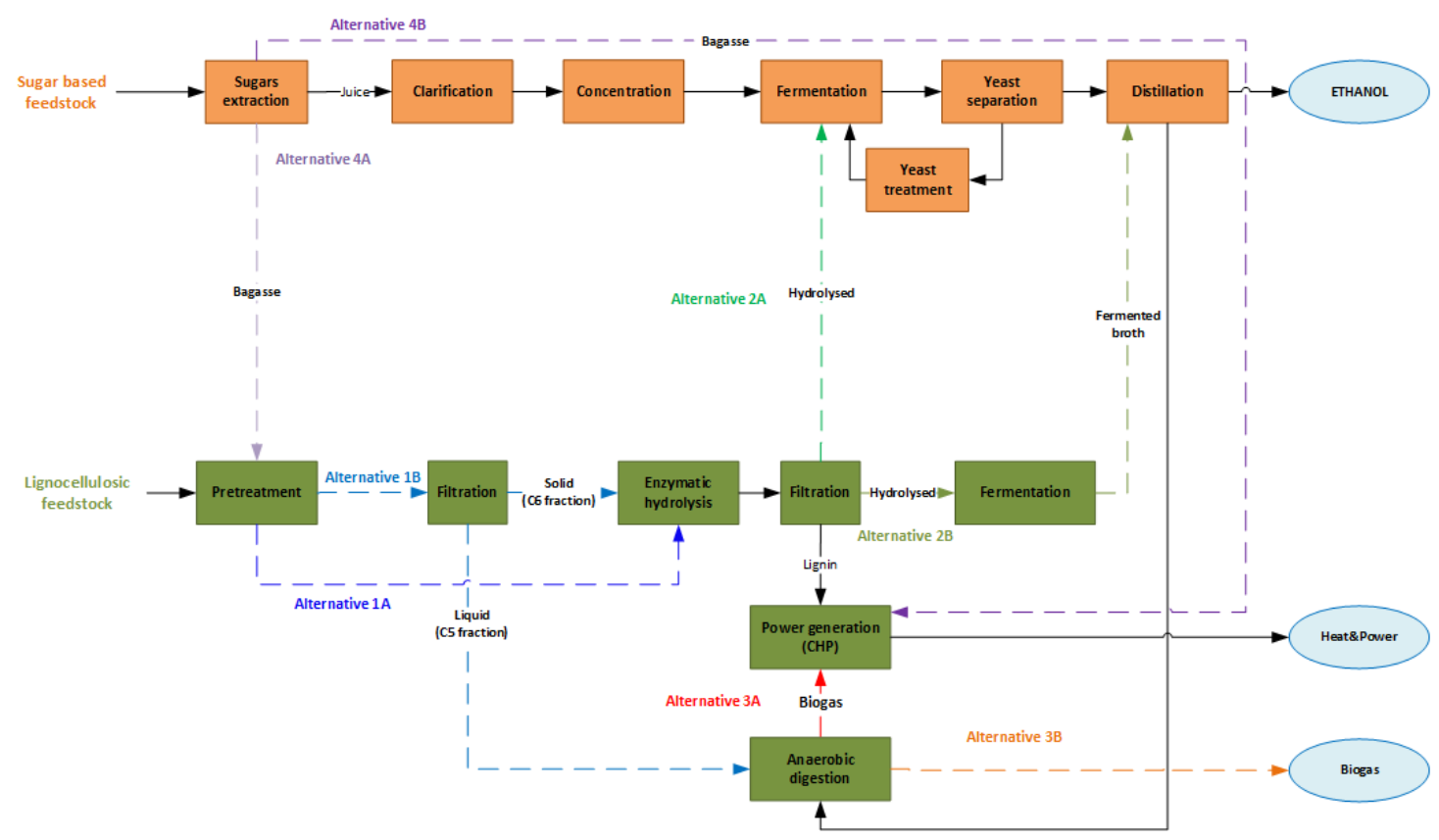

Figure 6. Possible configurations for the retrofitting of a sugar-based $1 \mathrm{G}$ facility.

Several studies can be found in the literature in which different process schemes are analyzed from a techno-economic and environmental point of view. For example, Joelsson et al. [137] evaluated the techno-economic feasibility of a plant based on $1 \mathrm{G}$ and $2 \mathrm{G}$ integration in the fermentation stage using grain and straw as feedstock. This study shows several alternative configurations considering the production of different co-products, such as energy or biogas. In all the case studies considered, the net present value (economic parameter that indicates the profits of the process during the project life) was positive and a minimum ethanol selling price between 0.45 and $0.53 € / L$ was obtained. Macrelli et al. [138] also analyzed the integration of $1 G$ and 2G plants from an economic point of view, using the whole sugarcane as feedstock. In this work, the integration between both plants was considered at the distillation stage, evaluating the influence of different technical parameters (enzymatic hydrolysis residence time, solid loading, the use of C5 fraction for obtaining ethanol or biogas, etc.) and economic parameters (feedstock, enzymes, electricity costs, etc.). Similar to the results obtained by Joelsson et al. [137], the net present value was positive for all the cases investigated, and a minimum ethanol selling price of $0.35-0.58 \$ / \mathrm{L}$ was obtained.

Watanabe et al. [139] evaluated the integration of $1 \mathrm{G}$ and 2G ethanol production in Brazil from an environmental point of view using life cycle assessment methodology. In this work, the case study evaluated considered a plant based on $1 \mathrm{G}$ and $2 \mathrm{G}$ integration using sugarcane, sugarcane straw, and bagasse as feedstock. The integration between both facilities was investigated at the fermentation stage. The study shows that the ethanol produced through this type of integration reduces the total greenhouse gas emissions by 1.6-fold compared to the stand-alone $1 \mathrm{G}$ ethanol facility, 12.9 vs. $21.1 \mathrm{~g}$ $\mathrm{CO}_{2}$-eq/MJ.

In the framework of the research project "Biorefinery2021—Energy from Biomass-New Paths to the Integrated Biorefinery" [140], several approaches for the optimization of ethanol plants were investigated, taking into account both stand-alone and $1 \mathrm{G}$ and $2 \mathrm{G}$ integration. In this project, initial plant concepts for the integration of $1 \mathrm{G}$ and $2 \mathrm{G}$ facilities using wheat and wheat straw were studied, showing that the specific investments for the construction of lignocellulose ethanol plants can be reduced by integrating them into existing $1 G$ plants [132].

Currently, as a part of the project "BIOFIT- Bioenergy Retrofits for Europe's industry", supported by the European Union's Horizon 2020 programme (https://www.biofit-h2020.eu/), the introduction of bioenergy retrofitting in the $1 \mathrm{G}$ ethanol industry is being investigated. One of the main objectives of 
this project is the development and evaluation of possible integration options, as well as the conditions under which this retrofit can be made. The BIOFIT project evaluates two integration scenarios for the existing $1 \mathrm{G}$ cereal-based ethanol plant of Biocarburantes de Castilla y Leon (BCyL) located in Babilafuente, Spain. The first scenario studies the production of $11,000 \mathrm{~m}^{3} /$ year of advanced bioethanol using as feedstock some waste streams listed in the Renewable Energy Directive II (RED II), such as wine alcohol and an ethanol-rich waste stream from a yeast production industry. The latter is under evaluation by the Spanish authorities to be included in that list. This scenario presents low technical complexity, low CAPEX, and, therefore, it could be quickly implemented. Figure 7 shows a descriptive flow sheet of the scenario 1 .

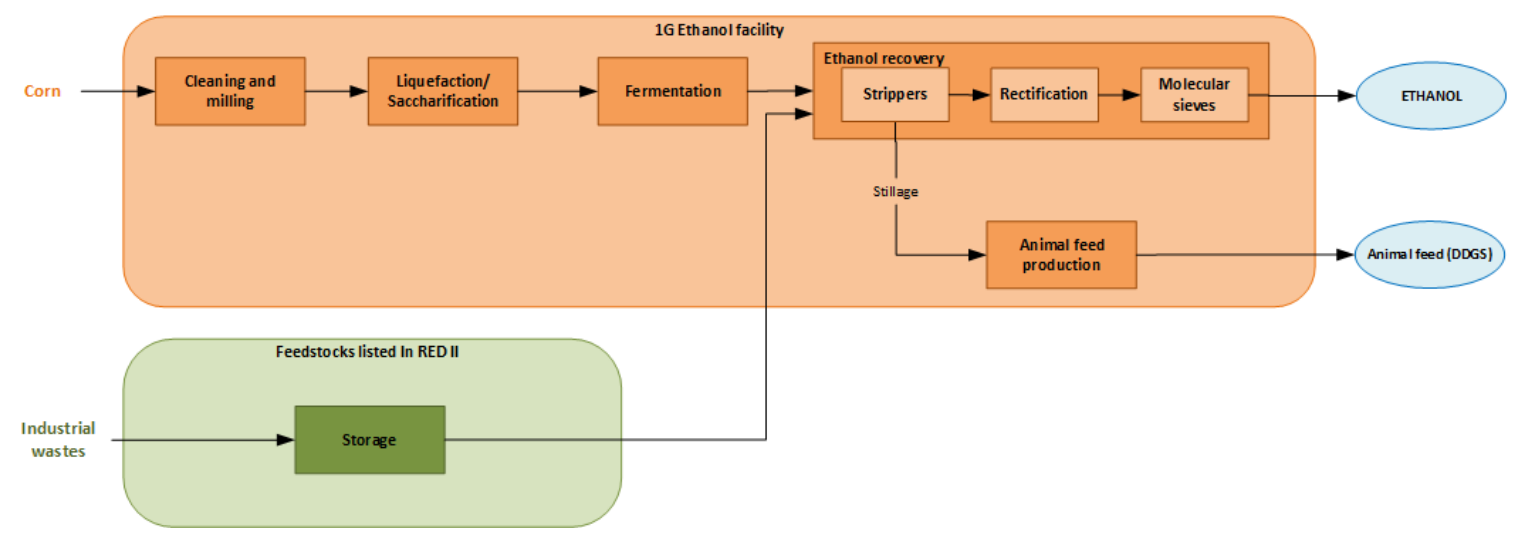

Figure 7. Descriptive flow sheet of the scenario 1.

The second scenario displayed in Figure 8 involves retrofitting of the existing $1 \mathrm{G}$ process to produce $19,000 \mathrm{~m}^{3}$ /year of advanced ethanol from corn stover, integrating $1 \mathrm{G}$ and $2 \mathrm{G}$ facilities at the distillation stage. In this scenario, corn stover is subjected to a pre-treatment process in a steam explosion unit obtaining two streams: a water-insoluble solid fraction (WIS) containing mainly glucose and lignin, and a liquid fraction (pre-hydrolysate) consisting mainly of xylose. The WIS fraction undergoes a presaccharification and simultaneous saccharification and fermentation process (PSSF) producing a bioethanol-rich stream. Afterwards, the bioethanol-rich stream is concentrated to about $50 \%$ in a distillation column (beer column). The remaining stillage and the pre-hydrolysate are then mixed together with the first generation in order to produce animal feed. On the other hand, the bioethanol stream is sent to the distillation area of the first-generation plant, where it is purified to about 99.9\%. The second scenario therefore requires several modifications, which will increase the duration, the capital investment, and expenditure compared to the values resulting from the first scenario.

In addition to the development and evaluation of particular retrofitting case studies, one of the main tasks of the BIOFIT project is to provide an overview on the challenges, barriers, and technical solutions for the biofuel sector and to give recommendations for policy makers. In the case of the bioethanol industry, a significant barrier is the low operational time of European 1G installations, since they are fairly new (most of them built after 2005). In this context, investing in the retrofitting of existing facilities may seem early from a plant investor's view. Some recommendations obtained through the BIOFIT project to promote biofuels and the retrofitting strategies in the sector are the following [141]:

1. The biofuels sector is heavily influenced by regulations. Changes in the regulation framework should be made with caution in order to keep running current $1 \mathrm{G}$ facilities' business plan. It seems difficult to get cellulosic ethanol without some benefits of $1 \mathrm{G}$ ethanol in the first place to allow them to invest in retrofitting strategies.

2. Biofuel producers have no direct access to the customers, which means little chance to promote the benefits of their products. Therefore, supplying different biofuels blends and advertising their benefits at the petrol station could motive the costumer to use them. 
3. The $\mathrm{CO}_{2}$ emissions of all fuels (fossil and biofuels) should be informed to customers at petrol stations to exemplify the benefits of using biofuels compared to fossil fuel.

4. Separate mandatory quotas for different biofuels' production helps to promote each one of them.

The other option of retrofitting is the so-called 1.5 generation $(1.5 \mathrm{G})$. This option consists in the transformation of the cellulosic sugars contained in the corn kernel fiber to produce ethanol. Corn kernels are separated in the conventional starch-based $1 \mathrm{G}$ process, being mainly made up of starch but also containing from $10 \%$ to $12 \%$ of fiber rich in cellulose and hemicellulose. The latter is easier to transform into ethanol than other lignocellulosic materials because it is a clean and homogenous feedstock with a small amount of lignin, making this material less recalcitrant [142]. According to the enzyme producer Novozyme, corn fiber needs mild pre-treatment and has less inhibitors. In addition, Novozyme shows experimental results in which it is observed that corn fiber can be easily digested with a low dose of enzymes. In fact, an equal conversion of the corn fiber to that of the corn stover can be obtained with a third of the enzyme dose [143].

Nowadays, different technologies are being developed to produce ethanol from the corn kernel fiber. As an example, D3MAX technology (Grand Forks, ND, USA), created by BBI International (Grand Forks, ND, USA) in 2015, allows the conversion of corn fiber and residual starch in a corn dry mill ethanol plant into cellulosic ethanol [144]. Figure 9 shows a schematic diagram describing the main stages of this technology.

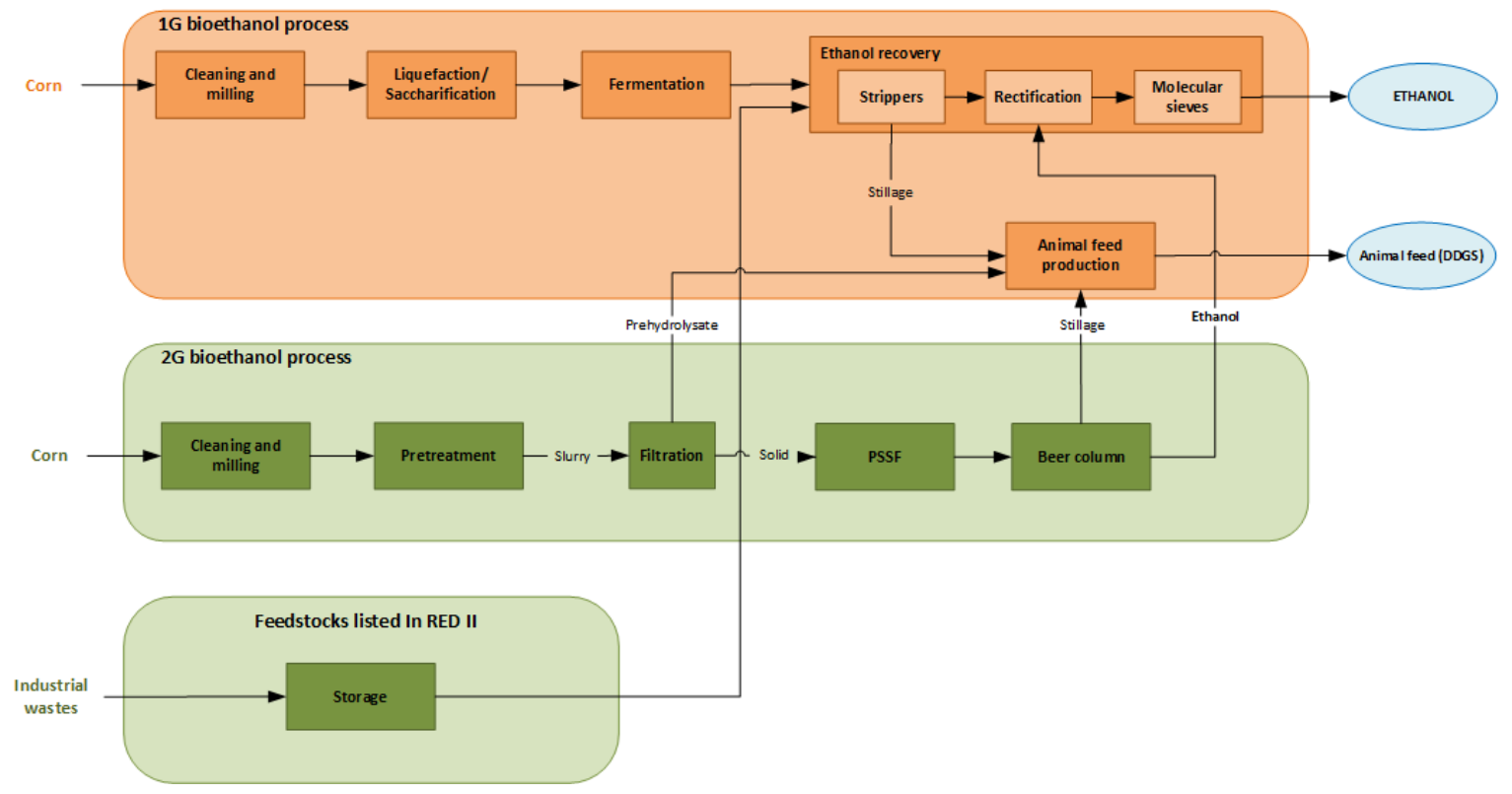

Figure 8. Descriptive flow sheet of the scenario 2.

In this process, the wet cake (containing the corn fiber) obtained by centrifugation of the stillage is subjected to a diluted acid pre-treatment in order to convert the cellulose and hemicellulose contained in that cake into monomeric sugars. The latter are then fermented to ethanol. Afterwards, the ethanol-rich stream obtained is then distilled in a beer column and then concentrated into anhydrous ethanol by rectification and dehydration in the same way as ethanol produced from corn starch. Finally, the stillage obtained from the bottom of the beer column is processed in the same manner as the stillage obtained in a 1G ethanol plant to produce animal feed (DDGS) [143]. D3MAX's first license was sold to Ace Ethanol in Stanley, WI, USA, in 2018. The construction of the Ace D3MAX system started in October of the same year and it will produce about 13.2 million L per year of cellulosic ethanol. This technology raises the overall ethanol yield of the plant by $11 \%$. At present, the start-up of this system has started $[143,145]$. 
Another example is the ICM'S patent-pending generation 1.5 Grain Fiber to Cellulosic Ethanol Technology (Colwich, KS, US). This method integrates a process for converting corn fiber to cellulosic ethanol in existing $1 \mathrm{G}$ ethanol plants. The system combines mechanical, chemical, and biological processes through the use of ICM's patented technologies, selective milling technology (SMT), and fiber separation technology (FST). Figure 10 shows a schematic diagram of this technology [142,145]. This technology has already been proven in 57,000-L pilot fermenters with an approximately 2 million L production working around $1000 \mathrm{~h}$. This process achieves up to a $10 \%$ increase in ethanol yield. The first full-scale installation was completed by the end of 2019 [146].

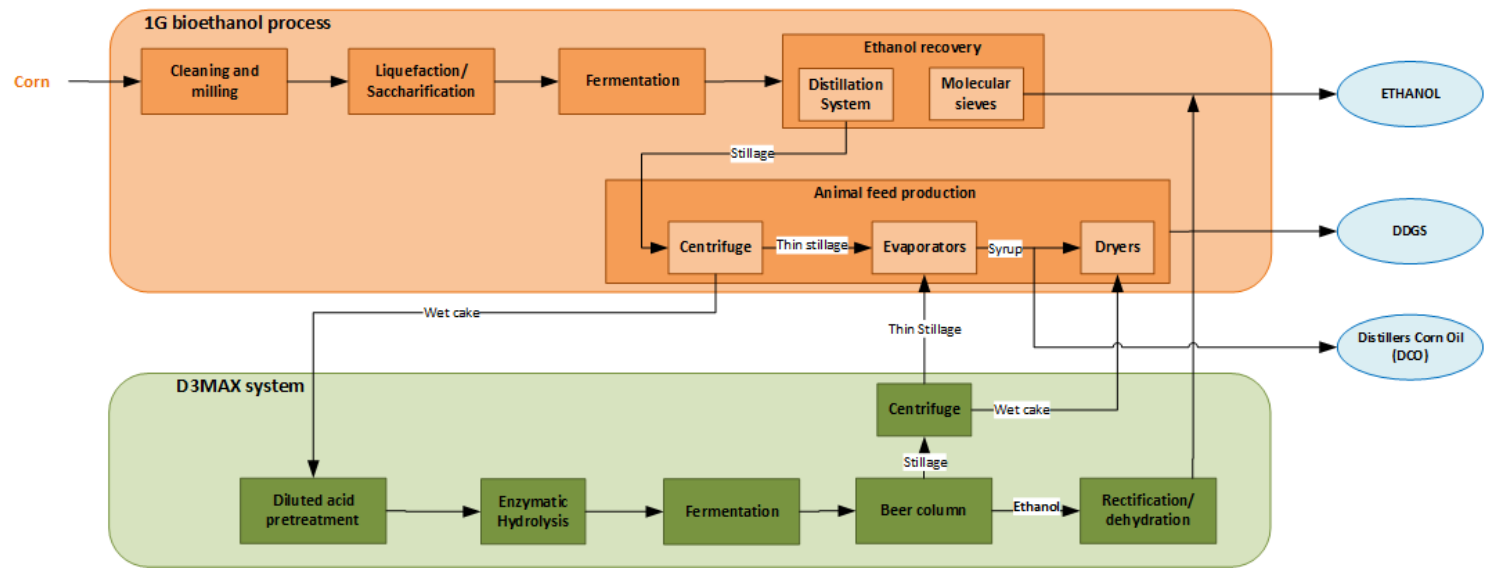

Figure 9. Schematic diagram of D3MAX technology (adapted from [143]).



Figure 10. Schematic diagram of ICM technology (adapted from [146]).

\subsection{Repurposing}

Repurposing of an $1 \mathrm{G}$ ethanol facility consists of modifying the production process of an existing $1 \mathrm{G}$ biofuel plant to produce $2 \mathrm{G}$ biofuels instead. At present, no $1 \mathrm{G}$ ethanol plant is known to have applied this modification.

\section{Bio-Based Products from Integrated Biorefineries}

Current fossil fuel prices are the major limiting factor for the commercialization of biofuels. This implies that they can only be introduced into the market through favorable government legislation or substantial tax discounts, as was discussed in Section 2. However, this artificial market is unlikely to last. Biofuel production costs must therefore be reduced significantly to create a sustainable market. Biorefineries have appeared as promising approaches to reduce these production costs. Biorefineries 
are analogous to oil refineries, where both high added-value products (e.g., food and feed, chemicals and materials) and biofuels can simultaneously be obtained from biomass resources within a very efficient integrated approach. IEA Bioenergy (Paris, France) defines biorefinery as an installation where a wide range of marketable products and energy are generated from biomass in a sustainable way [147]. Therefore, the co-production of high added-value bio-products together with biofuels should improve the overall economics of biorefinery operations and, in some cases, may even be the main source of revenue.

The biorefinery concept has already been developed in the past several decades together with the production of first-generation (1G) biofuels from sugar- or starch-containing feedstocks; in conventional facilities, in addition to producing these biofuels, animal feed (DDGS) and oleo-chemicals are generated [148]. Today, the transition to the production of advanced biofuels is driving the development of second-generation $(2 \mathrm{G})$ biorefineries. In these modern facilities, the use of lignocellulosic feedstocks is maximized in an integrated way to produce an expanded product portfolio, including biofuels and energy (heat and electricity) together with bio-based chemicals and materials [149]. Moreover, the development of these advanced biorefineries requires a sustainable design, including environmental, social, and economic aspects, along the full product value chain.

Operations in 2G biorefineries can be directed to transform lignocellulosic feedstock as a whole material by physical, chemical, and thermochemical technologies, the latter including fast pyrolysis, liquefaction, and gasification (Patel et al., 2016). The other main group of operations in these modern 2G biorefineries includes the separation of the principal components of lignocellulose, i.e., cellulose, hemicelluloses, and lignin, by physical, chemical, and/or biotechnological methods [58], which can be further transformed into a variety of biofuels and bio-products. The "sugar platform" is a representative example of this type of technology [150]. It is based on the saccharification of carbohydrates by enzymatic or chemical processes to produce soluble sugars. In the case of enzymatic hydrolysis, a prior pretreatment of lignocellulosic biomass is necessary to increase the accessibility of carbohydrates to enzymes [76]. Depending on the products to be obtained, the type of selected pretreatment varies. Those pretreatments based on the selective hemicellulose solubilization, i.e., hydrothermal processes in aqueous media or with added acidic catalysts (e.g., steam explosion and auto-hydrolysis), lead to a liquid stream enriched in potential prebiotic oligosaccharides, hemicellulosic sugars, furfural, levulinic acid, or low-molecular-weight phenolics, among others [151]. On the other hand, the solid residue remaining from hemicellulose solubilization, enriched in cellulose and lignin, can be hydrolyzed to give a glucose solution and a residual solid stream mainly made up of lignin (hydrolysis lignin), which is generally burned to generate heat and energy or employed as a substrate for gasification or pyrolysis [152,153]. Glucose and hemicellulosic sugars, i.e., xylose, arabinose, mannose, and galactose, serve as the primary substrates for many fermentation and chemical processes providing a variety of alcohols, organic acids, alkenes, lipids, and other chemicals [150]. High-value fine chemicals and products, such as amino acids, vitamins, antibiotics, and enzymes, can also be obtained.

Alternatively, pretreatments based on lignin solubilization can also yield a solid residue enriched in carbohydrates for subsequent enzymatic hydrolysis, and a liquid lignin side-stream [151], which along with the hydrolysis lignin constitute the "lignin platform" for the production of low-molecular-weight aromatics or materials [152,153]. Pretreatments based on delignification are the philosophy applied in the last decades in the pulp and paper industry, highlighting the kraft and sulphite pulping technologies [154]. The kraft mills produce energy from lignin-enriched black liquors through its concentration and burning, although current approaches based on the gasification of this side-stream are underway to improve the overall efficiency [152]. Sulphite mills obtain co-products from lignin (lignosulphonates), hemicellulosic sugars, and acetic acid [151]. Major applications for lignosulfonates are as dispersants, binders, and adhesives [152]. Recently, organosolv technology has emerged as an interesting approach for the production of high-purity lignin (i.e., sulphur free), increasing its potential as raw material to obtain a wide range of high added-value compounds (e.g., composites and polymers, 
resins, carbon fibers, aromatic compounds) [152,153]. In addition, the resulting solid residue from organosolv, enriched in cellulose and hemicellulose, is susceptible to subsequent enzymatic hydrolysis.

\subsection{Bio-Based Products from the "Sugar Platform"}

The "sugar platform" is considered by volume to be the largest platform for the production of bio-based chemicals and biofuels from lignocellulosic biomass [150]. It includes a mixture of C6 and C5 sugars from cellulose and hemicelluloses (e.g., glucose, mannose, galactose, xylose and arabinose). Post-processing of these sugars into bio-products is mainly via microbial fermentation (e.g., alcohols, organic acids, alkenes, lipids and other chemicals) [155], although chemical-based processes have also been developed (e.g., hydrogenation of glucose to sorbitol and acid dehydration of xylose to furfural) [156]. Furthermore, subsequent downstream processing of a particular bio-product increases even more the possibilities for obtaining a larger number of bio-based compounds [150]. In this context, the resulting primary compounds can therefore be considered as the end product (e.g., ethanol and butanol as biofuels and adipic acid for nylon production) or as building blocks for alternative end products. In this sense, the US Department of Energy (DOE) has identified several promising building block chemicals, including 2,5-furan dicarboxylic acid, 1,4-diacids (succinic, fumaric and malic), aspartic acid, glucaric acid, 3-hydroxy propionic acid, glutamic acid, itaconic acid, levulinic acid, 3-hydroxybutyrolactone, glycerol, sorbitol and xylitol/arabitol [157]. In the same way, other institutions (e.g., IEA Bioenergy and European Commission Directorate-General for Energy) have also listed several bio-based chemicals that can be obtained from the sugar platform and are in the demonstration stage or already commercialized [147,150,158].

(1) Products from sugars: fermentation based

Bacteria, fungi, and yeasts (genetically and non-genetically modified) have been widely used by the chemical industry to produce a high number of products by fermentation-based processes under different conditions (e.g., anaerobic/aerobic, low/high $\mathrm{pH}$ and enriched/limited nutrients) [155]. In 2013, above 110 million tons of fermentation products were obtained, accounting for 207 billion USD [158]. Among the different products, alcohols were the group with the largest share $(94 \%$ of volume and $87 \%$ of value), with ethanol fuel as its main representative. Similarly, production of fine chemicals increased to around 11 million tons. The projected market growth for fermentation products (e.g., alcohols, organic acids, polymers, amino acids, vitamins, antibiotics, and industrial enzymes) is $4.6 \%$ annually, $6.5 \%$ if excluding alcohols. Among the most important compounds are n-butanol and xylitol (alcohols); lactic acid, succinic acid, 3-hydroxypropionic acid, and itaconic acid (organic acids); polyhydroxyalkanoates (PHAs, polymer); and L-lysine (amino acid).

$n$-Butanol is an important chemical building block mainly used for the production of acrylate, methacrylate esters, glycol ethers, and butyl acetate [155]. Among them, butyl acetate is widely used as a solvent in paints, coatings for wood products, and also as a food flavoring [158]. Nevertheless, most of the industrial initiatives for n-butanol target the biofuels market (for gasoline replacement) as it has better fuel properties when compared to ethanol (i.e., higher energy content, lower water miscibility, and less corrosive properties) [155]. n-Butanol is produced by anaerobic bacteria (e.g., Clostridium acetobutylicum) and is co-produced with acetone and ethanol through the acetone-butanol-ethanol (ABE) fermentation route [159]. Cathay Industrial Bio (China) currently produces 100,000 tons/year of n-butanol for chemical applications [158].

Xylitol is a functional sweetener with applications in food, odontological, and pharmaceutical industries and has no petro-chemical substitute [157]. It can be produced from xylose by fermentation with microbial species belonging to the Candida genus [160], and also by catalytic hydrogenation [156]. Xylitol serves as a feedstock for the production of xylaric acid, glycols (e.g., propylene glycol, and ethylene glycol), lactic acid, and polyesters [157]. Total production is around 200,000 tons/year, with China being the main producer [158]. Highlights Dupont (Wilmington, DE, USA) produce xylitol from the xylose contained in the liquid side-streams generated in a sulphite pulp mill. 
Lactic acid is a bulk chemical also obtained via sugar fermentation. In 2019, this product reached a global production capacity of over 600,000 tons [158], highlighting the Dutch company Corbion (Gorinchem, The Netherlands) as the main producer [150]. There are numerous microorganisms capable of carrying out lactic fermentation, mainly bacteria, such as those belonging to Lactobacillus, Streptococcus, Leuconostoc, Enterococcus, and Bacillus genera [161]. Some filamentous fungi (Mucor, Monilia, and Rhizopus) can also perform lactic fermentation. The main applications of lactic acid are in the food sector (acidity regulator) and in cosmetics (softeners, creams). Additionally, lactic acid can be used in the pharmaceutical and chemical industries as solvent and as feedstock for lactate ester production [157]. Lactic acid is also used for the production of polylactic acid (PLA), which is considered a suitable polymer in the packaging, insulation, automotive, and fibers industries [155]. The company NatureWorks (Blair, Nebraska, USA) is the main global leader in PLA production [150]. In Europe, the demand for PLA is currently 25,000 tons/year, and could potentially reach 650,000 tons/year in 2025 [158].

Succinic acid has traditionally been produced by the petro-chemical industry from n-butane through catalytic hydrogenation of maleic acid or maleic anhydride [155]. It can also be produced via sugar fermentation at low $\mathrm{pH}$ using either yeast or bacteria (e.g., Actinobacillus succinogenes) [162]. In Europe, there are two main producers for succinic acid, Reverdia (consortium between the Dutch company DSM and the French company Roquette with a large scale-plant in Cassano Spinola, Italy) and Succinity (the joint venture between Corbion and the German company BASF with a plant located in Montmeló, Spain), while BioAmber (Montreal, QC, Canada) and Myriant (Lake Providence, LA, USA) are two major global companies for this product [150]. Succinic acid can be used in personal care products and food additives (acidity regulator), as well as plasticizers, polyurethanes, resins, and coatings. It is also a chemical building block for the production of 1,4-butanediol, tetrahydrofurane, gammabutyrolactone, and polybutylene succinate, considered an important polymer in the production of bioplastics [158]. In 2013, the production costs of bio-succinic acid equaled the fossil-derived succinic acid [150], and even cheaper when considering a larger production scale (typically $50 \mathrm{ktons}$ ). It is also important to note that the production of succinic acid from carbohydrates significantly reduces GHG emissions compared to its petro-chemical equivalent.

3-Hydroxypropionic acid is obtained by using a genetically modified E. coli strain. This chemical is mainly used for the production of acrylic acid via dehydration [150,163]. Acrylic acid is an important chemical building block to obtain polyacrylates and commodity acrylates (e.g., methyl, ethyl, n-butyl, and 2-ethylhexyl acrylate). The global market for acrylic acid is about 13.21 USD billion and it is used in plastics, coatings, adhesives, textiles, resins, detergents and cleaners, and elastomers (synthetic rubbers), as well as in floor polishes and paints $[150,158]$. This bio-based product significantly reduces GHG emissions compared to petro-chemical equivalents ( $>70 \%)$, and major acrylic acid producers are BASF-Cargill-Novozymes (Ludwigshafen, Germany-Minneapolis, MN, USA-Copenhagen, Denmark) and OPXBio-Dow (Boulder, CO, USA-Midland, MI, USA).

Itaconic acid is a naturally occurring, non-toxic, and readily biodegradable white crystalline powder produced from xylose fermentation by Aspergillus terreus [150,155]. It is considered an important building block in the chemical industry, where it can be used to produce lubricants and as a co-monomer in the paper and architectural coating industry for the production of acrylonitrile-butadiene-styrene and acrylate latexes. Together with acrylamide, itaconic acid can be used for the synthesis of hydrogels that can be applied as controlled dosage systems for active ingredients, such as pesticides and drugs. Itaconic acid production has been estimated at 40,000 and 70,000 tons/year, with China as the main producer [158].

PHAs are a class of linear polyesters produced by many species of bacteria (e.g., Pseudomonas species) from sugars or lipids under growth conditions characterized by an excess carbon source and limitation of other nutrients, such as nitrogen and phosphorus [150,155]. These natural plastics are biodegradable and can either be thermoplastic or elastomeric materials. Polyhydroxybutyrate (PHB) is one of the most important PHAs due to its similar mechanical, physical, and thermal properties 
to many different plastics, such as polypropylene, polyethylene, polyvinylchloride, polystyrene, and polyethylene terephthalate. It is used in the medical sector for internal suture, in the pharmaceutical industry for capsules and packaging, replacing polystyrene to make foam, and in automotive, design, and high-tech electronics [157]. This bio-based product shows a significant reduction in GHG emissions (>90\%) compared to the petrochemical equivalents when using lignocellulosic as the substrate [150]. The markets for PHAs are potentially equally large to synthetic polypropylene and polyethylene, with Biomer and Bio-on being the key European producers, and Metabolix the largest in the USA.

L-lysine is an essential amino acid used as a supplement in animal nutrition, with a global market of over 1.7 million tons in 2014 and is expected to reach over 2.7 million tons by 2023 [42]. Evonik (Essen, Germany) is the only company that produces this amino acid. It is obtained from glucose by Corynebacterium glutamicum, although the use of engineered microorganisms capable of using pentoses has also been demonstrated.

(2) Products from sugars: chemical based

Sugars can also be subjected to chemical processes (e.g., selective dehydration, hydrogenation, and oxidation reactions) to obtain useful products, such as sorbitol, levulinic acid, and furan derivatives [156].

Sorbitol is produced by catalytic hydrogenation of glucose, and has no fossil-based substitute. Several global companies target the production of sorbitol, which reaches an annual volume of about 1.8 million tons [164]. Sorbitol is mainly used as food additive or as feedstock to obtain other products, such as surfactants and polyurethanes. Additionally, it can be further converted into ascorbic acid (80,000 tons/year by combining the biotechnological/chemical process), sorbitan (50,000 tons/year), isosorbide (by selective dehydration), and 1,2-propanediol (by hydrogenolysis) [158].

Levulinic acid is generally produced by isomerization of glucose to fructose, which is subsequently subjected to dehydration to obtain HMF, which further yields levulinic acid and formic acid (by-product) by hydrolysis [157]. Xylose and arabinose can also be used as substrate by including a reduction step (via furfuryl alcohol) [158]. Levulinic acid is used in pharmaceuticals, pesticides, cosmetics, and food additives. Other minor uses include nylons, synthetic rubbers, and plastics. As a chemical building block, levulinic acid is greatly important for biorefineries [165], serving as feedstock for the production of relevant chemicals, such as fuel additives (methyltetrahydrofuran) and pesticides ( $\delta$-aminolevulinic acid), plasticizers (diphenolic acid), and even potential biofuels (methyltetrahydrofuran, valerolactone, and ethyl levulinate) [150]. The production of diphenolic acid is of particular interest as it can replace bisphenol $\mathrm{A}$ in the production of polycarbonates.

Furfural is produced by dehydration of xylose or arabinose and has no petro-chemical alternative. The production of furfural has been estimated at around 200,000-360,000 tons/year worldwide, of which $60-70 \%$ is transformed into furfuryl alcohol by hydrogenation [166]. Other furan derivatives include HMF, 5-chloromethylfurfural, 2,5-furandicarboxylic acid (FDCA), and 2,5-dimethylfuran. Special attention is for FDCA, which is obtained from oxidation of HMF and can be used in the production of polyester polymers to replace terephthalic acid. Furthermore, FDCA can be considered an alternative to adipic acid, levulinic acid, and succinic acid.

Table 2 summarizes the different bio-based products from the sugar platform considered in this section. 
Table 2. List of bio-based products from the sugar platform.

\begin{tabular}{|c|c|c|}
\hline Product & Production Processes & Application \\
\hline$n$-Butanol & $\begin{array}{l}\text { Acetone-butanol-ethanol (ABE) } \\
\text { fermentation }\end{array}$ & $\begin{array}{l}\text { Chemical building block: production of acrylate, } \\
\text { methacrylate esters, glycol ethers, and butyl acetate } \\
\text { Biofuel }\end{array}$ \\
\hline Xylitol & $\begin{array}{l}\text { Xylose fermentation with microbial } \\
\text { species (Candida genus) } \\
\text { Catalytic hydrogenation }\end{array}$ & $\begin{array}{l}\text { Sweetener: used in food, odontological, and pharmaceutical } \\
\text { industries } \\
\text { Chemical building block: production of xylaric acid, glycols, } \\
\text { lactic acid, and polyesters }\end{array}$ \\
\hline Lactic acid & $\begin{array}{l}\text { Lactic fermentation mainly with } \\
\text { bacteria, (Lactobacillus, Streptococcus, } \\
\text { Leuconostoccus, Enterococcus), and some } \\
\text { filamentous fungi (Mucor, Monilia, } \\
\text { Rhizopus) }\end{array}$ & $\begin{array}{l}\text { Acidity regulator in food industry } \\
\text { Cosmetics (softeners, creams) } \\
\text { Solvent in pharmaceutical and chemical industries } \\
\text { PLA production }\end{array}$ \\
\hline $\begin{array}{l}\text { 3-Hydroxypropionic } \\
\text { acid }\end{array}$ & $\begin{array}{l}\text { Sugar fermentation with a genetically } \\
\text { modified } E \text {. coli strain }\end{array}$ & Acrylic acid production \\
\hline PHAs & $\begin{array}{l}\text { Sugars or lipids fermentation with } \\
\text { many species of bacteria (e.g., } \\
\text { Pseudomonas species) }\end{array}$ & $\begin{array}{l}\text { Natural plastics: applications in medicine (internal suture), } \\
\text { in pharmaceutical industry (capsules and packaging), } \\
\text { replacing polystyrene to make foam, and in automotive, } \\
\text { design, and high-tech electronics }\end{array}$ \\
\hline L-lysine & Glucose fermentation by C. glutamicum & Supplement in animal nutrition \\
\hline Sorbitol & Catalytic hydrogenation of glucose & $\begin{array}{l}\text { Food } \\
\text { Surfactants and polyurethanes production }\end{array}$ \\
\hline Furfural & Dehydration of xylose or arabinose & $\begin{array}{l}\text { Main use: furfuryl alcohol production } \\
\text { Other uses: HMF, 5-chloromethylfurfural, FDCA, and } \\
\text { 2,5-dimethylfuran production }\end{array}$ \\
\hline
\end{tabular}

FDCA: 2,5-furandicarboxylic acid; HMF: 5-hydroxymethylfurfural; PHAs: polyhydroxyalkanoates; PLA: polylactic acid.

\subsection{Bio-Based Products from the "Lignin Platform"}

Lignin is the most abundant renewable aromatic resource on earth. Through its main intrinsic properties, such as hydrophobicity, UV stabilizer, plasticer, poly-electrolite, aromatic structure, and multifunctional groups, lignin serves as a renewable feedstock for the production of fuels, chemicals, and materials [167]. Depending on the pretreatment technology and conditions, as well as the isolation process, the intrinsic properties of lignin can be further modified [168]. Additionally, chemical, thermal, and enzymatic modification can modulate these properties for the desired products $[152,169]$.

Currently, the main source of lignin is the pulp and paper industry. Approximately, 50-70 million tons/year of lignin are generated at pulp and paper industry mills worldwide, mainly from those mills based on kraft and sulphite pulping technologies, such as Borregaard LignoTech (Sarpsborg, Norway), Tembec Inc. (Montreal, QC, Canada), Domsjö Fabriker AB (Örnsköldsvik, Sweden), or Nippon Paper Industries Co. LTD (Chiyoda, Japan) [152,169]. Kraft lignin and lignosulphonate prices fluctuate between 260 and 500 USD/MT and 180 and 500 USD/MT, respectively. By 2030, lignin production is estimated to increase up to 225 million tons/year, when advanced $2 \mathrm{G}$ biorefineries become fully operational. This $2 \mathrm{G}$ lignin could either be in the form of lower quality hydrolysis lignin or high-purity lignin isolated as part of the pretreatment [170], such as organolsov lignin commercialized by Repap 
Enterprises Inc. (Montreal, QC, Canada), CIMV (Neuilly-sur-Seine, France) and Suzano (São Paulo, Brazil), with prices varying between 280 and 520 USD/MT [152,169].

To date, lignin is mainly combusted to generate internal energy in the pulp and paper industry in the form of heat and electricity. Lignin from advanced biorefineries may also be directed towards combustion, reducing both the operation costs and the life cycle GHG emissions in these facilities [152,153]. However, in 2G biorefineries, approximately $60 \%$ more lignin is generated than what is needed to meet plant energy requirements through combustion [171]. Therefore, different research efforts are accelerating to identify viable opportunities for valorizing this residue into chemicals and materials. Among the alternative potential applications of lignin, we found its degradation to low-molecular-weight aromatics or its use as a multi-functional macromolecule.

\section{(1) Lignin as a feedstock for low-molecular-weight aromatics}

Lignin depolymerization into low-molecular-weight aromatics is the main approach to produce specialty fuels and chemicals $[153,169]$. Due to its complex structure, lignin depolymerization is very challenging, and different approaches have emerged towards this goal, including thermochemical treatments (e.g., gasification and pyrolysis), hydroprocessing (e.g., hydrogenolysis and hydrodeoxygenation), and oxidation processes (e.g., chemical and biological) [172].

Lignin gasification in the presence of oxygen produces a mixture of gases (syngas), including hydrogen $\left(\mathrm{H}_{2}\right)$, carbon monoxide (CO), and a very small amount of $\mathrm{CO}_{2}$ [173]. Syngas can be used in heating, cooking, and electricity, but its main interest lies in coupling this product with catalytic or fermentation processes to produce methanol/dimethyl-ether, a mix of alcohols, and green diesel through Fischer-Tropsch technology [174]. Lignins derived from steam explosion and enzymatic hydrolysis have been subjected to gasification only to a limited extent on a bench and pilot scale [175].

Thermal degradation of lignin by pyrolysis (i.e., in the absence of oxygen) generates solid biochar, syngas, and bio-oil as the main byproducts [171]. This technology has been applied on the lignin resulting from the hydrolysis of wheat straw during bioethanol production, obtaining a bio-oil mostly composed of oxygenated aromatics coming from the lignin monomers (guaiacol-, syringol-, and phenol-derived compounds) [176]. Lignin can also be transformed to BTX (benzene, toluene, and xylene) by pyrolysis coupled to hydrodeoxygenation [177]. BTX is an important chemical product. It is the source of $60 \%$ of the aromatics currently placed on the market, and up to $24 \%$ of the total petro-chemical market [178]. BTX has an average price of $1200 \mathrm{USD} /$ ton, and its annual demand exceeds 100 million tons, thus accounting for a market of ca. 100 billion USD [179]. Although lignin-based BTX is currently in the R\&D stage, its commercialization is expected to start in the coming years [152].

Reductive depolymerization of lignin by hydrogenolysis, in combination with metal catalysts, can lead to liquefied mixtures containing hydrogenated products (linear and branched hydrocarbons, and cycle hydrocarbons) and substituted phenols [171]. This technology has received substantial attention to be integrated into the $2 \mathrm{G}$ bioethanol process by treating the lignin-rich phase of biomass after enzymatic deconstruction and fermentation with an alkaline hydrogenation stage to produce a green diesel/gasoline resource [180]. Additionally, hydrodeoxygenation of lignin followed by demethoxylation produces phenols, which are currently produced from petroleum-based benzene via cumene. The global market for phenol is around 8 million metric tons, valued at 1000-2000 USD/ton in 2010 [169]. Phenols are widely used in the production of formaldehyde resins as well as polyurethane [178]. Phenols also have potential application in the cosmetic, plastic, pharmaceutical, food, and perfumery industry [152]. The advantage of phenol from lignin compared to phenol from petroleum is that it has a stable market value price of $1.22-1.46 \mathrm{USD} / \mathrm{kg}$.

Lignin oxidation involves catalytic side-chain oxidation and fragmentation reactions, resulting in aromatic acids and aldehydes or ring-opened organic acids [181]. Oxygen, peroxide, peracetic acid, and air are usually used as an oxidant, and organometallics, acid and bases, and metal salts as catalysts [172]. Vanillin is a well-known product of lignin oxidation. It is used as a flavoring agent in food, beverages, and pharmaceuticals [152]. The synthetic vanillin has a marked price of about 12,000 USD/MT [178], 
and up to $20 \%$ of the total synthetic vanillin comes from lignin [169]. The main lignin-based vanillin commercial production is attributed to Borregaard Lignoctech (Sarpsborg, Norway) [178], which utilizes oxidative depolymerization of lignosulfonates from sulphite pulping. Nevertheless, some studies have explored the production of vanillin by catalytic oxidative depolymerization of the lignin resulting after enzymatic hydrolysis during lignocellulosic ethanol production, and from hardwood organosolv lignin, using different metal salts-based catalysts $[182,183]$. The oxidative depolymerization of lignin by biological processes (mainly by oxidative enzymes, such as laccases and peroxidases) into various phenolic and aromatic compounds is also gaining particular attention [184].

\section{(2) Lignin as a multi-functional macromolecule}

The recalcitrant nature of lignin makes the depolymerization strategy energy intensive and expensive. Therefore, the direct use of lignin as a macromolecule for the production of high added-value materials without the need of depolymerization is a promising approach $[153,169]$. Indeed, about $75 \%$ of the commercial lignin-derived products take advantage of this property [177]. Some of the lignin-based materials with major projection include carbon materials (carbon fiber and activated carbon), resins (phenol-formaldehyde and polyurethane), hydrogels, and polymer modifiers, among others.

Carbon fiber has multiple applications, especially in the automotive industry where this composite material could replace structural steel [169]. The global demand for carbon fiber is estimated to be 140,000 tons, accounting for 4.5 billion USD [152]. However, its high price (18 USD $/ \mathrm{kg}$ ) is a major limitation [178]. The reason for the high costs is the high price of its precursor, polyacrylonitrile (PAN), which costs $15 \mathrm{USD} / \mathrm{kg}$ [177]. In this context, lignin can be used as an alternative to PAN and consequently make the process rather cheap. The process involves several production techniques, such as the melting spin of lignin, oxidative stabilization of lignin fiber, carbonization under $\mathrm{N}_{2}$, and surface treatment sizing [153]. However, certain issues must be solved prior to the use of lignin as a precursor of carbon fiber. This includes improving its mechanical properties to those compared with traditional PAN-based carbon fiber and overcoming the difficulties in melt spinning. These challenges have been addressed through several strategies, such as purification and chemical modification of lignin [177]. Carbon fiber has been produced using kraft lignin from hardwood and softwood materials [152]. Lignin resulting from $2 \mathrm{G}$ biorefineries could also be considered an important precursor for the synthesis of carbon fiber. The Oak Ridge National Laboratory (ORNL) is currently leading the development of high-quality low-cost lignin-based carbon fiber with an estimated price value of $12 \mathrm{USD} / \mathrm{kg}$, which is close to the target range for the automotive industry [177].

Lignin can be also converted into a range of carbon materials, including active carbon, graphitic carbon, or carbon black [152]. These materials are produced by thermochemical processes and can be used in manufacture, energy storage, catalysis, and pollutant removal [185]. For instance, lignins derived from organosolv pretreatment and enzymatic hydrolysis have been valorized with different applications, such as the electrode material in supercapacitors, or as an adsorbent in environmental water remediation [186]. The market price for activated carbons shows great fluctuations between 500 USD/MT and 62,000 USD/MT, which very much depends on its properties and applications [169].

Phenol-formaldehyde (PF) resins are the most commonly used adhesive in the industry, such as wood bonding, insulation, lamination, or plywood adhesives. In 2010, the market value for PF accounted for 10 billion USD, although annual values are estimated to be 4.5 to 6 billion USD [169]. Lignin is a good candidate for the replacement of petro-chemical phenol in PF resins due to its polyphenolic nature. However, the low reactivity of lignin to formaldehyde promotes partial phenol replacement in PF (up to $50 \%$ ) when non-modified lignin is used. Different strategies (e.g., demethylation, phenolation, and methylolation) have been assayed towards improving the low reactivity of lignin to formaldehyde [187], reaching up to $100 \%$ phenol replacement when modified lignin from cellulosic bioethanol from corn stover was used [188].

Lignin is also a promising feedstock for the production of more environmentally friendly thermoset resin polyurethane. Polyurethane is a highly versatile polymer with a great number of applications, 
such as the shipbuilding, automotive, furniture insulation, and packaging industries [152]. In 2015, the global polyurethane industry accounted for 52 USD billion of revenue, which is expected to increase up to 77 USD billion by 2023 [177]. Polyurethane production is performed through the so-called urethanization process that includes the reaction of diisocyanates and polyols with terminal hydroxyl groups. These polyols can be replaced by lignin due to its phenolic nature, resulting in lignin-based polyurethanes with superior physical properties in some cases [189]. The urethanization reaction has also been assayed for the production of lubricant-oleogels from eucalypt and pine kraft and hydrolysis-derived lignins, which were functionalized with diisocyanate and subsequently dispersed in castor oil [190].

Biopolymer-based hydrogels are one of the most typical materials for biological, biomedical, and environmental applications, including drug delivery, living tissue, healing system, and water purification processes [169]. These hydrogels are either a physically or chemically cross-linked three-dimensional hydrophilic network with the capacity to retain water or other solvents up to thousands of times their dry weight without being dissolved. Due to its biocompatibility, biodegradability, low toxicity, and its susceptibility to enzymatic degradation, lignin can also be considered as raw material for the production of natural polymer-based hydrogels [191].

Other applications of lignin as a macromolecule include polymer modifiers. This is due to the antioxidant and radical scavenging ability for UV protection of lignin [187]. In this context, lignin can be blended with polymers, such as polyethylene, polypropylene, and natural rubber, thus improving their thermal oxidative resistance [192]. It can also be used as a fire retardant since it reduces the flammability of polymers, such as polypropylene, polybutylene succinate, polyethylene terephthalate, and acrylonitrile butadiene styrene [193]. In the same way, the blending of lignin with polymers, such as methyl methacrylate and styrene, has received special attention in the field of thermoplastic elastomers, polymeric foams, and membranes [153].

Table 3 below shows a list of the lignin-derived compounds discussed in this section, highlighting the main production pathways and relevant applications.

Taking into the account all the different products that can be obtained, the advanced biorefinery approach opens many opportunities for the production of biofuels in conjunction with hundreds of bio-based chemicals and materials from sugars and lignin in a very efficient integrated approach. This strategy might generate 10 billion USD revenues for the chemical industry globally [158] and reduce the production costs of the biofuels by about $30 \%$, which would make them more competitive with fossil fuels. In this sense, several techno-economic studies have demonstrated the feasibility of co-producing biofuels and bio-products. Then, splitting a carbohydrate stream (4:1) in a grain ethanol plant for co-production of ethanol and lactic acid could reduce the required ethanol sale price from 775 to $545 €$ per ton [194]. In the same way, the valorization of the xylose liquid stream from steam-exploded corn stover to xylitol or furfural, together with the thermal conversion of residual hydrolysis lignin, could reduce the ethanol selling price from the glucose solid stream from $1.62 € / \mathrm{kg}$ in the case base to $0.79 € / \mathrm{kg}$ [195]. Nevertheless, although the co-production of bio-based chemicals and materials might contribute to solving the economic challenges of advanced biofuels, the full deployed integration of bio-products and biofuels production in the biorefinery context still requires different supports regarding feedstock availability, logistic and supply, technology, process design, financial, regulatory, and social acceptance. 
Table 3. List of bio-based products from the lignin platform.

\begin{tabular}{|c|c|c|}
\hline Product & Production Processes & Application \\
\hline Syngas & $\begin{array}{l}\text { Gasification } \\
\text { Pyrolysis }\end{array}$ & $\begin{array}{l}\text { Chemical building block: methanol, ethanol, dimethyl-ether, mixed of } \\
\text { alcohols, carboxylic acids, and Fischer-Tropsch green diesel } \\
\text { Heating, cooking and electricity }\end{array}$ \\
\hline Hydrocarbons & $\begin{array}{l}\text { Pyrolysis coupled to } \\
\text { hydrodeoxygenation } \\
\text { Hydrogenolysis }\end{array}$ & $\begin{array}{l}\text { Benzene-toluene-xylene: source of aromatics } \\
\text { Linear and branched hydrocarbons: green diesel/gasoline resource }\end{array}$ \\
\hline Phenols & $\begin{array}{l}\text { Pyrolysis } \\
\text { Hydrodeoxygenation followed by } \\
\text { demethoxylation } \\
\text { Biological (laccases and peroxidases) }\end{array}$ & $\begin{array}{l}\text { Bio-oil (guaiacol-, syringol-, and phenol-derived compounds) } \\
\text { Phenols for production of formaldehyde resins as well as } \\
\text { polyurethane } \\
\text { Phenols for potential application in cosmetic, plastic, pharmaceutical, } \\
\text { food, and perfumery industry }\end{array}$ \\
\hline Oxidized products & $\begin{array}{l}\text { Chemical (oxidants in presence of } \\
\text { catalysts) } \\
\text { Biological (laccases and peroxidases) }\end{array}$ & Vanillin: flavoring agent in food, beverages and pharmaceuticals \\
\hline Carbon fiber & $\begin{array}{l}\text { Melting spin of lignin, oxidative } \\
\text { stabilization of lignin fiber, } \\
\text { carbonization under } \mathrm{N}_{2} \text {, and surface } \\
\text { treatment sizing }\end{array}$ & Replace structural steel in automotive industry \\
\hline Carbon materials & Pyrolysis & $\begin{array}{l}\text { Active carbon, graphitic carbon or carbon black: manufacture, energy } \\
\text { storage, catalysis, and pollutant removal }\end{array}$ \\
\hline $\begin{array}{l}\text { Phenol- } \\
\text { formaldehyde resins }\end{array}$ & Lignin as phenol replacement & $\begin{array}{l}\text { Adhesive in the industry such as wood bonding, insulation, } \\
\text { lamination or plywood adhesives }\end{array}$ \\
\hline Polyurethane resins & Lignin as polyol replacement & $\begin{array}{l}\text { Shipbuilding, automotive, furniture insulation, and packaging } \\
\text { industries }\end{array}$ \\
\hline Oleogels & Lignin urethanization reaction & Biolubricants \\
\hline Hydrogels & $\begin{array}{l}\text { Copolymerization } \\
\text { Crosslinking }\end{array}$ & $\begin{array}{l}\text { Biological, biomedical and environmental applications, including } \\
\text { drug delivery, living tissue, healing system, and water purification } \\
\text { processes }\end{array}$ \\
\hline Polymer blends & $\begin{array}{l}\text { Extrusion with lignin previously } \\
\text { modified }\end{array}$ & $\begin{array}{l}\text { Lignin blended with polyethylene, polypropylene, and natural rubber } \\
\text { to improve their thermal oxidative resistance } \\
\text { Lignin blended with polypropylene, polybutylene succinate, } \\
\text { polyethylene terephthalate, and acrylonitrile butadiene styrene as } \\
\text { flame retardant } \\
\text { Lignin blended with methyl methacrylate and styrene in the field of } \\
\text { thermoplastic elastomers, polymeric foams, and membranes }\end{array}$ \\
\hline
\end{tabular}

\section{Concluding Remarks}

Transportation is an important sector with a significant share of the global energy consumption. It highly contributes to global warming, making the necessity of introducing alternative and renewable forms of energy an imperative. Among the different options available today, bioethanol is the most widespread liquid biofuel worldwide. It is mainly produced from the sugars contained in biomass by microbial fermentation processes and can be used in today's cars directly in ethanol/gasoline blends up to $10 \%$, or in higher proportions in specific modified engines.

Even though the ethanol industry has shown its viability at the commercial scale for the production of the so-called $1 \mathrm{G}$ bioethanol from food-based products, a shift is needed towards increasing the production volumes of advanced bioethanol and to reach a more sustainable production process. Hence, the use of non-food materials, such as lignocellulose, algal biomass, or industrial-derived wastes, may be considered excellent options to replace those feedstocks directly linked to the food market. Lignocellulosic bioethanol production by means of biochemical processes (also known as $2 \mathrm{G}$ bioethanol or cellulosic ethanol) has attained a level of development close to commercialization, and great efforts have been made to place this product in the market. However, the difficulties found in accessing and releasing the fermentable sugars of the lignocellulosic materials represent an important limiting factor for the implementation and deployment of such technology at a large scale due to the increase in the overall process costs.

Other options are now being investigated towards a cost-effective advanced bioethanol production. Pathways, such as the thermo-catalytic route (biomass gasification and catalytic conversion of syngas), 
the hybrid route (biomass gasification and syngas fermentation), or the glycerol route (fermentation or catalytic conversion of glycerol generated during biodiesel production), have appeared as interesting choices for the conversion of a great variety of biomass feedstocks. Significant advances have been reached up to now in the different mentioned technologies, although further research is needed to reach a mature stage in all of them and demonstrate their technical feasibility and economic viability at a large scale.

Another possibility with high potential for reducing current $2 \mathrm{G}$ production costs in the short to medium term is the integration of $2 \mathrm{G}$ technology within an existing $1 \mathrm{G}$ facility. This strategy appears as an excellent option to ease the transition from $1 G$ to $2 G$ biofuels, offering several alternatives, such as retrofitting, co-locating, or repurposing. Furthermore, this approach could result in synergies and cost savings, supporting the establishment of $2 \mathrm{G}$ ethanol production technologies. For the long term, it is, however, important to stress the relevance of co-producing both bioethanol (and biofuels in general) and high added-value products (e.g., chemicals, materials, food and feed products), from a wide range of biomass resources within an efficient and integrated biorefinery concept.

Author Contributions: Conceptualization, A.D.M. and P.M.; Writing-original draft preparation, A.S., R.M.S., D.I., M.E.E., P.M. and A.D.M.; writing-review and editing, A.S., R.M.-S., D.I., M.E.E., P.M. and A.D.M.; Visualization, A.S.; Supervision, R.I., P.M. and A.D.M.; funding acquisition, P.M., R.I., M.E.E. and D.I. All authors have read and agreed to the published version of the manuscript.

Funding: This research was partially funded by the Regional Government of Madrid (Project SUSTEC-CM S2018/EMT-4348), the Spanish MICIU (Projects RTI2018-96080-B-C22 and ENE2017-85819-C2-2-R), and the European Commission (BIOFIT Project; H2020 Grant agreement 817999). R.M.S. also acknowledges the Spanish MICIU for a "Juan de la Cierva-Incorporación" contract (IJCI-2016-28403).

Conflicts of Interest: The authors declare no conflict of interest. The funders had no role in the design of the study; in the collection, analyses, or interpretation of data; in the writing of the manuscript, or in the decision to publish the results.

\section{References}

1. Imran, A.; Varman, M.; Masjuki, H.H.; Kalam, M.A. Review on alcohol fumigation on diesel engine: A viable alternative dual fuel technology for satisfactory engine performance and reduction of environment concerning emission. Renew. Sustain. Energy Rev. 2013, 26, 739-751. [CrossRef]

2. IEA. $\mathrm{CO}_{2}$ Emissions Statistics; International Energy Agency: Paris, France, 2018 . Available online: https://www.iea.org/data-and-statistics? country=WORLD\&fuel=CO2\%20emissions\&indicator= CO2\%20emissions\%20by\%20sector (accessed on 1 September 2020).

3. Tomás-Pejó, E.; Moreno, A.D. Alcohol fuels: The biochemical route. In Biofuels Production and Processing Technology; Riazi, M.R., Chiaramonti, D., Eds.; CRC Press: Boca Raton, FL, USA, 2017; pp. 341-360.

4. Posada, J.A.; Patel, A.D.; Roes, A.; Blok, K.; Faaij, A.P.C.; Patel, M.K. Potential of bioethanol as a chemical building block for biorefineries: Preliminary sustainability assessment of 12 bioethanol-based products. Bioresour. Technol. 2013, 135, 490-499. [CrossRef]

5. Minteer, S. Alcoholic fuels: An overview. In Alcoholic Fuels; Minteer, S., Ed.; Taylor and Francis: Boca Raton, FL, USA, 2006; pp. 1-4.

6. ePure. Fuelling Europe's Future: A Vision for How Renewable Ethanol Can Help Drive the EU Green Deal; ePure: Brussels, Belgium, 2020. Available online: https://www.epure.org/news-and-media/news/ fuelling-europes-future-a-vision-for-how-renewable-ethanol-can-help-drive-the-eu-green-deal (accessed on 1 September 2020).

7. Satari, B.; Karimi, K.; Kumar, R. Cellulose solvent-based pretreatment for enhanced second-generation biofuel production: A review. Sustain. Energy Fuels 2019, 3, 11-62. [CrossRef]

8. ENERDATA. Global Energy Statistical Yearbook; ENERDATA: Grenoble, France, 2019. Available online: https: //yearbook.enerdata.net/total-energy/world-consumption-statistics.html (accessed on 1 September 2020).

9. REN21. Renewables 2019: Global Status Report; REN21 Secretariat: Paris, France, 2019. Available online: https: //www.ren21.net/wp-content/uploads/2019/05/gsr_2019_perspectives_en.pdf (accessed on 1 September 2020). 
10. Saygin, D.; Kempener, R.; Wagner, N.; Ayuso, M.; Gielen, D. The Implications for renewable energy innovation of doubling the share of renewables in the global energy mix between 2010 and 2030. Energies 2015, 8, 5828-5865. [CrossRef]

11. RFA. 2020 RFA's Ethanol Industry Outlook; Renewable Fuels Association: Ellisville, MO, USA, 2020. Available online: https:/ethanolrfa.org/wp-content/uploads/2020/02/2020-Outlook-Final-for-Website.pdf (accessed on 1 September 2020).

12. OdC. Fuel Consumption; Observatório da Cana: São Paulo, Brazil, 2020. Available online: https: //observatoriodacana.com.br (accessed on 1 September 2020).

13. Mączyńska, J.; Krzywonos, M.; Kupczyk, A.; Tucki, K.; Sikora, M.; Pińkowska, H.; Bacczyk, A.; Wielewska, I. Production and use of biofuels for transport in Poland and Brazil-The case of bioethanol. Fuel 2019, 241, 989-996. [CrossRef]

14. Barros, S.; Flake, O. Brazil Biofuels Annual 2019; USDA Foreign Agricultural Service: Washington, DC, USA, 2019. Available online: https://apps.fas.usda.gov/newgainapi/api/report/downloadreportbyfilename? filename=Biofuels\%20Annual_Sao\%20Paulo\%20ATO_Brazil_8-9-2019.pdf (accessed on 1 September 2020).

15. ePure. European Renewable Ethanol-Key FiguRes. 2018; ePure: Brussels, Belgium, 2019. Available online: https://epure.org/media/1920/190828-def-data-statistics-2018-infographic.pdf (accessed on 1 September 2020).

16. Ebadian, M.; McMillan, J.D.; Saddler, J.J.N.; van Dyk, S. Implementation Agendas: 2018-2019 Update Compare and Contrast Transport Biofuels Policies; International Energy Agency: Paris, France, 2019. Available online: http://task39.sites.olt.ubc.ca/files/2020/02/IEA-Bioenergy-Task-39-Implementation-Agendas-FinalDraft-Feb-4-2020.pdf (accessed on 1 September 2020).

17. EU. Directive 2009/28/EC of the European Parliament and of the Council of 23 April 2009 on the Promotion of the Use of Energy from Renewable Sources and Amending and Subsequently Repealing Directives 2001/77/EC and 2003/30/EC; European Parliament, Council of the European Union: Brussels, Belgium, 2009. Available online: http://data.europa.eu/eli/dir/2009/28/oj (accessed on 1 September 2020).

18. EU. Directive (EU) 2018/2001 of the European Parliament and of the Council of 11 December 2018 on the Promotion of the Use of Energy from Renewable Sources; European Parliament, Council of the European Union: Brussels, Belgium, 2018. Available online: https://eur-lex.europa.eu/eli/dir/2018/2001/oj (accessed on 1 September 2020).

19. Giuntoli, J. Advanced Biofuel Policies in Select EU Member States: 2018 Update; International Council on Clean Transportation: Washington, DC, USA, 2018. Available online: https:/theicct.org/sites/default/files/ publications/Advanced_biofuel_policy_eu_update_20181130.pdf (accessed on 1 September 2020).

20. RFA. 2019 RFA's Ethanol Industry Outlook; Renewable Fuels Association: Ellisville, MO, USA, 2019. Available online: https://ethanolrfa.org/wp-content/uploads/2019/02/RFA2019Outlook.pdf (accessed on 1 September 2020).

21. Collotta, M.; Champagne, P.; Tomasoni, G.; Alberti, M.; Busi, L.; Mabee, W. Critical indicators of sustainability for biofuels: An analysis through a life cycle sustainabilty assessment perspective. Renew. Sustain. Energy Rev. 2019, 115, 109358. [CrossRef]

22. Tenenbaum, D.J. Food vs. fuel diversion of crops could cause more hunger. Environ. Health Perspect. 2008, 116, A254-A257. [CrossRef] [PubMed]

23. Tomei, J.; Helliwell, R. Food versus fuel? Going beyond biofuels. Land Use Policy 2016, 56, 320-326. [CrossRef]

24. Filip, O.; Janda, K.; Kristoufek, L.; Zilberman, D. Food versus fuel: An updated and expanded evidence. Energy Econ. 2019, 82, 152-166. [CrossRef]

25. Rosillo-Calle, F. Food versus fuel: Toward a new paradigm-The need for a holistic approach. ISRN Renew. Energy 2012, 2012, 954180. [CrossRef]

26. EU. Directive (EU) 2015/1513 of the European Parliament and of the Council of 9 September 2015 Amending Directive 98/70/EC Relating to the Quality of Petrol and Diesel Fuels and Amending Directive 2009/28/EC on the Promotion of the Use of Energy from Renewable Sources; European Parliament, Council of the European Union: Brussels, Belgium, 2015. Available online: http://data.europa.eu/eli/dir/2015/1513/oj (accessed on 1 September 2020).

27. US-SA. The Renewable Fuel Standard and Biofuels Policy; The US Sustainability Alliance: Washington, DC, USA, 2020. Available online: https://thesustainabilityalliance.us/biofuels/ (accessed on 1 September 2020).

28. Guinée, J. Life cycle sustainability assessment: What is it and what are its challenges? In Taking Stock of Industrial Ecology; Springer: Berlin, Germany, 2015; pp. 45-68. 
29. Gnansounou, E.; Dauriat, A.; Villegas, J.; Panichelli, L. Life cycle assessment of biofuels: Energy and greenhouse gas balances. Bioresour. Technol. 2009, 100, 4919-4930. [CrossRef]

30. Saddler, J.; McMillan, J.; Ebadian, M. Comparison of International Life Cycle Assessment (LCA) Biofuels Models; International Energy Agency: Paris, France, 2019. Available online: https://www.ieabioenergy.com/wpcontent/uploads/2019/07/IEABio-T39_summary_LCA_final.pdf (accessed on 1 September 2020).

31. Zarrilli, S.; Burnett, J. Making Certification Work for Sustainable Development: The Case of Biofuels; United Nations: Geneva, Switzerland, 2008. Available online: https://unctad.org/en/Docs/ditcted20081_en.pdf (accessed on 1 September 2020).

32. Vohra, M.; Manwar, J.; Manmode, R.; Padgilwar, S.; Patil, S. Bioethanol production: Feedstock and current technologies. J. Environ. Chem. Eng. 2014, 2, 573-584. [CrossRef]

33. Wyman, C.E. Ethanol fuel. In Encyclopedia of Energy; Cleveland, C.J., Ed.; Elsevier: New York, NY, USA, 2004; pp. 541-555.

34. Naylor, R.L.; Liska, A.J.; Burke, M.B.; Falcon, W.P.; Gaskell, J.C.; Rozelle, S.D.; Cassman, K.G. The ripple effect: Biofuels, food security, and the environment. Environ. Sci. Policy Sustain. Dev. 2007, 49, 30-43. [CrossRef]

35. Cheng, J.J.; Timilsina, G.R. Status and barriers of advanced biofuel technologies: A review. Renew. Energy 2011, 36, 3541-3549. [CrossRef]

36. Amorim, H.V.; Lopes, M.L.; De Castro Oliveira, J.V.; Buckeridge, M.S.; Goldman, G.H. Scientific challenges of bioethanol production in Brazil. Appl. Microbiol. Biotechnol. 2011, 91, 1267-1275. [CrossRef] [PubMed]

37. Chum, H.L.; Warner, E.; Seabra, J.E.A.; Macedo, I.C. A comparison of commercial ethanol production systems from Brazilian sugarcane and US corn. Biofuel Bioprod. Biorefin. 2014, 8, 205-223. [CrossRef]

38. Marques, S.; Moreno, A.D.; Ballesteros, M.; Gírio, F. Starch biomass for biofuels, biomaterials, and chemicals. In Biomass and Green Chemistry: Building a Renewable Pathway; Vaz, S., Jr., Ed.; Springer International Publishing: Cham, Switzerland, 2018; pp. 69-94.

39. Urbanchuk, J.M.; Kowalski, D.J.; Dale, B.; Kim, S. Corn amylase: Improving the efficiency and environmental footprint of corn to ethanol through plant biotechnology. AgBioForum 2009, 12, 149-154.

40. Kumar, D.; Singh, V. Dry-grind processing using amylase corn and superior yeast to reduce the exogenous enzyme requirements in bioethanol production. Biotechnol. Biofuels 2016, 9, 228. [CrossRef]

41. Balan, V.; Chiaramonti, D.; Kumar, S. Review of US and EU initiatives toward development, demonstration, and commercialization of lignocellulosic biofuels. Biofuel Bioprod. Biorefin. 2013, 7, 732-759. [CrossRef]

42. Rosales-Calderon, O.; Arantes, V. A review on commercial-scale high-value products that can be produced alongside cellulosic ethanol. Biotechnol. Biofuels 2019, 12, 240. [CrossRef]

43. Brown, A.; Waldheim, L.; Landälv, I.; Saddler, J.; Ebadian, M.; McMillan, J.D.; Bonomi, A.; Klein, B. Advanced Biofuels_Potential for Cost Reduction; IEA Bioenergy: Paris, France, 2020. Available online: https://www. ieabioenergy.com/wp-content/uploads/2020/02/T41_CostReductionBiofuels-11_02_19-final.pdf (accessed on 1 September 2020).

44. Yu, Y.-S.; Giles, B.; Oh, V. State of the Market Report-Uncovering the Cost of Cellulosic Ethanol Production; Luxresearch: Boston, MA, USA, 2016. Available online: https://members.luxresearchinc.com/research/report/ 18478 (accessed on 1 September 2020).

45. Moreno, A.D.; Alvira, P.; Ibarra, D.; Tomás-Pejó, E. Production of ethanol from lignocellulosic biomass. In Production of Platform Chemicals from Sustainable Resources; Fang, Z., Smith, R.L., Qi, X., Eds.; Springer Nature: Singapore, 2017; pp. 375-410.

46. IEA-RETD. Towards Advanced Biofuels_Options for Integrating Conventional and Advanced Biofuel Production Sites (RES-T-BIOPLANT); IEA Implementing Agreement for Renewable Energy Technology Deployment (IEA-RETD): Utrecht, The Netherlands, 2016. Available online: http://iea-retd.org/wp-content/uploads/2016/ 08/20160202-IEA-RETD-RES-T-BIOPLANT-1.pdf (accessed on 1 September 2020).

47. Halder, P.; Azad, K.; Shah, S.; Sarker, E. Prospects and technological advancement of cellulosic bioethanol ecofuel production. In Advances in Eco-Fuels for a Sustainable Environment; Azad, K., Ed.; Woodhead Publishing: Sawston, UK, 2019; pp. 211-236.

48. Mohamed Abdul Ghani, N.M.A.; Vogiatzis, C.; Szmerekovsky, J. Biomass feedstock supply chain network design with biomass conversion incentives. Energy Policy 2018, 116, 39-49. [CrossRef]

49. Alkasrawi, M.; Galbe, M.; Zacchi, G. Recirculation of process streams in fuel ethanol production from softwood based on simultaneous saccharification and fermentation. Appl. BioChem. Biotechnol. 2002, 98, 849-861. [CrossRef] 
50. Alkasrawi, M.; Eriksson, T.; Börjesson, J.; Wingren, A.; Galbe, M.; Tjerneld, F.; Zacchi, G. The effect of Tween-20 on simultaneous saccharification and fermentation of softwood to ethanol. Enzym. Microb. Technol. 2003, 33, 71-78. [CrossRef]

51. Gurram, R.N.; Al-Shannag, M.; Lecher, N.J.; Duncan, S.M.; Singsaas, E.L.; Alkasrawi, M. Bioconversion of paper mill sludge to bioethanol in the presence of accelerants or hydrogen peroxide pretreatment. Bioresour. Technol. 2015, 192, 529-539. [CrossRef]

52. Susmozas, A.; Moreno, A.D.; Romero-García, J.M.; Manzanares, P.; Ballesteros, M. Designing an olive tree pruning biorefinery for the production of bioethanol, xylitol and antioxidants: A techno-economic assessment. Holzforschung 2019, 73, 15-23. [CrossRef]

53. Dávila, J.A.; Rosenberg, M.; Cardona, C.A. A biorefinery for efficient processing and utilization of spent pulp of Colombian Andes Berry (Rubus glaucus Benth.): Experimental, techno-economic and environmental assessment. Bioresour. Technol. 2017, 223, 227-236.

54. Moncada, J.; Cardona, C.A.; Higuita, J.C.; Vélez, J.J.; López-Suarez, F.E. Wood residue (Pinus patula bark) as an alternative feedstock for producing ethanol and furfural in Colombia: Experimental, techno-economic and environmental assessments. Chem. Eng. Sci. 2016, 140, 309-318. [CrossRef]

55. Schubert, T. Production routes of advanced renewable $\mathrm{C} 1$ to $\mathrm{C} 4$ alcohols as biofuel components-A review. Biofuel Bioprod. Biorefin. 2020, 14, 845-878. [CrossRef]

56. Stephen, J.D.; Mabee, W.E.; Saddler, J.N. Will second-generation ethanol be able to compete with first-generation ethanol? Opportunities for cost reduction. Biofuel Bioprod. Biorefin. 2012, 6, 159-176. [CrossRef]

57. Valdivia, M.; Galan, J.L.; Laffarga, J.; Ramos, J.L. Biofuels 2020: Biorefineries based on lignocellulosic materials. Microb Biotechnol. 2016, 9, 585-594. [CrossRef] [PubMed]

58. Moreno, A.D.; Tomás-Pejó, E.; Ballesteros, M.; Negro, M.J. Pretreatment technologies for lignocellulosic biomass deconstruction within a biorefinery perspective. In Biofuels: Alternative Feedstocks and Conversion Processes for the Production of Liquid and Gaseous Biofuels, 2nd ed.; Pandey, A., Larroche, C., Dussap, C.-G., Gnansounou, E., Khanal, S.K., Ricke, S., Eds.; Academic Press: Amsterdam, The Netherlands, 2019; pp. 379-399.

59. Taherzadeh, M.J.; Karimi, K. Pretreatment of lignocellulosic wastes to improve ethanol and biogas production: A review. Int. J. Mol Sci. 2008, 9, 1621-1651. [CrossRef] [PubMed]

60. Lin, M.; Ryu, G.H. Effects of thermomechanical extrusion and particle size reduction on bioconversion rate of corn fiber for ethanol production. Cereal Chem. 2014, 91, 366-373. [CrossRef]

61. Duque, A.; Manzanares, P.; Ballesteros, I.; Negro, M.J.; Oliva, J.M.; Gonzalez, A.; Ballesteros, M. Sugar production from barley straw biomass pretreated by combined alkali and enzymatic extrusion. Bioresour. Technol. 2014, 158, 262-268. [CrossRef]

62. Alvira, P.; Tomás-Pejó, E.; Ballesteros, M.; Negro, M.J. Pretreatment technologies for an efficient bioethanol production process based on enzymatic hydrolysis: A review. Bioresour. Technol. 2010, 101, 4851-4861. [CrossRef] [PubMed]

63. Smith, M.D.; Mostofian, B.; Cheng, X.; Petridis, L.; Cai, C.M.; Wyman, C.E.; Smith, J.C. Cosolvent pretreatment in cellulosic biofuel production: Effect of tetrahydrofuran-water on lignin structure and dynamics. Green Chem. 2016, 18, 1268-1277. [CrossRef]

64. Tadesse, H.; Luque, R. Advances on biomass pretreatment using ionic liquids: An overview. Energy Environ. Sci. 2011, 4, 3913-3929. [CrossRef]

65. Socha, A.M.; Parthasarathi, R.; Shi, J.; Pattathil, S.; Whyte, D.; Bergeron, M.; George, A.; Tran, K.; Stavila, V.; Venkatachalam, S.; et al. Efficient biomass pretreatment using ionic liquids derived from lignin and hemicellulose. Proc. Natl. Acad. Sci. USA 2014, 111, E3587-E3595. [CrossRef]

66. Smith, E.L.; Abbott, A.P.; Ryder, K.S. Deep eutectic solvents (DESs) and their applications. Chem. Rev. 2014, 114, 11060-11082. [CrossRef] [PubMed]

67. Galbe, M.; Wallberg, O. Pretreatment for biorefineries: A review of common methods for efficient utilisation of lignocellulosic materials. Biotechnol. Biofuels 2019, 12, 294. [CrossRef] [PubMed]

68. Yang, B.; Wyman, C.E. Pretreatment: The key to unlocking low-cost cellulosic ethanol. Biofuel Bioprod. Biorefin. 2008, 2, 26-40. [CrossRef] 
69. Duque, A.; Manzanares, P.; Ballesteros, I.; Ballesteros, M. Steam explosion as lignocellulosic biomass pretreatment. In Biomass Fractionation Technologies for a Lignocellulosic Feedstock Based Biorefinery; Mussatto, S.I., Ed.; Elsevier: Amsterdam, The Netherlands, 2016; pp. 349-368.

70. da Costa Sousa, L.; Jin, M.; Chundawat, S.P.S.; Bokade, V.; Tang, X.; Azarpira, A.; Lu, F.; Avci, U.; Humpula, J.; Uppugundla, N.; et al. Next-generation ammonia pretreatment enhances cellulosic biofuel production. Energy Environ. Sci. 2016, 9, 1215-1223. [CrossRef]

71. Martín-Sampedro, R.; Fillat, U.; Ibarra, D.; Eugenio, M.E. Use of new endophytic fungi as pretreatment to enhance enzymatic saccharification of Eucalyptus globulus. Bioresour. Technol. 2015, 196, 383-390. [CrossRef] [PubMed]

72. Moreno, A.D.; Ibarra, D.; Alvira, P.; Tomás-Pejó, E.; Ballesteros, M. A review of biological delignification and detoxification methods for lignocellulosic bioethanol production. Crit. Rev. Biotechnol. 2015, 35, 342-354. [CrossRef]

73. Fillat, U.; Ibarra, D.; Eugenio, M.E.; Moreno, A.D.; Tomás-Pejó, E.; Martín-Sampedro, R. Laccases as a potential tool for the efficient conversion of lignocellulosic biomass: A review. Fermentation 2017, 3, 17. [CrossRef]

74. Sun, Y.; Cheng, J. Hydrolysis of lignocellulosic materials for ethanol production: A review. Bioresour. Technol. 2002, 83, 1-11. [CrossRef]

75. Taherzadeh, M.J.; Karimi, K. Acid-based hydrolysis processes for ethanol from lignocellulosic materials: A review. BioResources 2007, 2, 472-499.

76. Alvira, P.; Ballesteros, M.; Negro, M.J. Progress on enzymatic saccharification technologies for biofuels production. In Biofuel Technologies: Recent Developments; Gupta, V.K., Tuohy, M.G., Eds.; Springer: Berlin/Heidelberg, Germany, 2013; pp. 145-169.

77. Moreno, A.D.; Ibarra, D.; Eugenio, M.E.; Tomás-Pejó, E. Laccases as versatile enzymes: From industrial uses to novel applications. J. Chem. Technol. Biotechnol. 2020, 95, 481-494. [CrossRef]

78. Horn, S.J.; Vaaje-Kolstad, G.; Westereng, B.; Eijsink, V.G. Novel enzymes for the degradation of cellulose. Biotechnol. Biofuels 2012, 5, 45. [CrossRef]

79. Jørgensen, H.; Kristensen, J.B.; Felby, C. Enzymatic conversion of lignocellulose into fermentable sugars: Challenges and opportunities. Biofuel Bioprod. Biorefin. 2007, 1, 119-134. [CrossRef]

80. Tomás-Pejó, E.; Oliva, J.M.; Ballesteros, M. Realistic approach for full-scale bioethanol production from lignocellulose: A review. J. Sci. Ind. Res. 2008, 67, 874-884.

81. Eliasson, A.; Christensson, C.; Wahlbom, C.F.; Hahn-Hägerdal, B. Anaerobic xylose fermentation by recombinant Saccharomyces cerevisiae carrying XYL1, XYL2, and XKS1 in mineral medium chemostat cultures. Appl. Environ. Microbiol. 2000, 66, 3381-3386. [CrossRef] [PubMed]

82. Zaldivar, J.; Borges, A.; Johansson, B.; Smits, H.P.; Villas-Boas, S.G.; Nielsen, J.; Olsson, L. Fermentation performance and intracellular metabolite patterns in laboratory and industrial xylose-fermenting Saccharomyces cerevisiae. Appl. Microbiol. Biotechnol. 2002, 59, 436-442.

83. Chandrakant, P.; Bisaria, V.S. Simultaneous bioconversion of glucose and xylose to ethanol by Saccharomyces cerevisiae in the presence of xylose isomerase. Appl. Microbiol. Biotechnol. 2000, 53, 301-309. [CrossRef] [PubMed]

84. Karhumaa, K.; García Sánchez, R.; Hahn-Hägerdal, B.; Gorwa-Grauslund, M.F. Comparison of the xylose reductase-xylitol dehydrogenase and the xylose isomerase pathways for xylose fermentation by recombinant Saccharomyces cerevisiae. Microb. Cell Fact 2007, 6, 5. [CrossRef]

85. Chu, B.C.H.; Lee, H. Genetic improvement of Saccharomyces cerevisiae for xylose fermentation. Biotechnol. Adv. 2007, 25, 425-441. [CrossRef] [PubMed]

86. Komeda, H.; Yamasaki-Yashiki, S.; Hoshino, K.; Asano, Y. Identification and characterization of D-xylulokinase from the D-xylose-fermenting fungus, Mucor circinelloides. FEMS Microbiol. Lett. 2014, 360, 51-61. [CrossRef]

87. Millati, R.; Edebo, L.; Taherzadeh, M.J. Performance of Rhizopus, Rhizomucor, and Mucor in ethanol production from glucose, xylose, and wood hydrolyzates. Enzym. Microb. Technol. 2005, 36, 294-300. [CrossRef]

88. Zhang, M.; Eddy, C.; Deanda, K.; Finkelstein, M.; Picataggio, S. Metabolic engineering of a pentose metabolism pathway in ethanologenic Zymomonas mobilis. Science 1995, 267, 240-243. [CrossRef]

89. Gorsich, S.W.; Dien, B.S.; Nichols, N.N.; Slininger, P.J.; Liu, Z.L.; Skory, C.D. Tolerance to furfural-induced stress is associated with pentose phosphate pathway genes ZWF1, GND1, RPE1, and TKL1 in Saccharomyces cerevisiae. Appl. Microbiol. Biotechnol. 2006, 71, 339-349. [CrossRef] 
90. Tomás-Pejó, E.; Olsson, L. Influence of the propagation strategy for obtaining robust Saccharomyces cerevisiae cells that efficiently co-ferment xylose and glucose in lignocellulosic hydrolysates. Microb. Biotechnol. 2015, 8, 999-1005. [CrossRef] [PubMed]

91. Ruyters, S.; Mukherjee, V.; Verstrepen, K.J.; Thevelein, J.M.; Willems, K.A.; Lievens, B. Assessing the potential of wild yeasts for bioethanol production. J. Ind. Microbiol. Biotechnol. 2015, 42, 39-48. [CrossRef] [PubMed]

92. Martorell, P.; Stratford, M.; Steels, H.; Fernandez-Espinar, M.T.; Querol, A. Physiological characterization of spoilage strains of Zygosaccharomyces bailii and Zygosaccharomyces rouxii isolated from high sugar environments. Int. J. Food Microbiol. 2007, 114, 234-242. [CrossRef] [PubMed]

93. Scully, S.; Orlygsson, J. Recent advances in second generation ethanol production by thermophilic bacteria. Energies 2014, 8, 1-30. [CrossRef]

94. Moshi, A.P.; Hosea, K.M.; Elisante, E.; Mamo, G.; Mattiasson, B. High temperature simultaneous saccharification and fermentation of starch from inedible wild cassava (Manihot glaziovii) to bioethanol using Caloramator boliviensis. Bioresour. Technol. 2015, 180, 128-136. [CrossRef] [PubMed]

95. Tavva, S.S.M.D.; Deshpande, A.; Durbha, S.R.; Palakollu, V.A.R.; Goparaju, A.U.; Yechuri, V.R.; Bandaru, V.R.; Muktinutalapati, V.S.R. Bioethanol production through separate hydrolysis and fermentation of Parthenium hysterophorus biomass. Renew Energy 2016, 86, 1317-1323. [CrossRef]

96. Da Costa Nogueira, C.; de Araújo Padilha, C.E.; de Jesus, A.A.; de Santana Souza, D.F.; de Assis, C.F.; de Sousa Junior, F.C.; dos Santos, E.S. Pressurized pretreatment and simultaneous saccharification and fermentation with in situ detoxification to increase bioethanol production from green coconut fibers. Ind. Crop. Prod. 2019, 130, 259-266. [CrossRef]

97. Siriwong, T.; Laimeheriwa, B.; Aini, U.N.; Cahyanto, M.N.; Reungsang, A.; Salakkam, A. Cold hydrolysis of cassava pulp and its use in simultaneous saccharification and fermentation (SSF) process for ethanol fermentation. J. Biotechnol. 2019, 292, 57-63. [CrossRef]

98. Sakimoto, K.; Kanna, M.; Matsumura, Y. Kinetic model of cellulose degradation using simultaneous saccharification and fermentation. Biomass Bioenergy 2017, 99, 116-121. [CrossRef]

99. Geijer, C.; Faria-Oliveira, F.; Moreno, A.D.; Stenberg, S.; Mazurkewich, S.; Olsson, L. Genomic and transcriptomic analysis of Candida intermedia reveals the genetic determinants for its xylose-converting capacity. Biotechnol. Biofuels 2020, 13, 48. [CrossRef]

100. Olson, D.G.; McBride, J.E.; Shaw, A.J.; Lynd, L.R. Recent progress in consolidated bioprocessing. Curr. Opin. Biotechnol. 2012, 23, 396-405. [CrossRef]

101. Parisutham, V.; Kim, T.H.; Lee, S.K. Feasibilities of consolidated bioprocessing microbes: From pretreatment to biofuel production. Bioresour. Technol. 2014, 161, 431-440. [CrossRef] [PubMed]

102. Shao, X.; Jin, M.; Guseva, A.; Liu, C.; Balan, V.; Hogsett, D.; Dale, B.E.; Lynd, L. Conversion for avicel and AFEX pretreated corn stover by Clostridium thermocellum and simultaneous saccharification and fermentation: Insights into microbial conversion of pretreated cellulosic biomass. Bioresour. Technol. 2011, 102, 8040-8045. [CrossRef] [PubMed]

103. Jin, M.; Gunawan, C.; Balan, V.; Dale, B.E. Consolidated bioprocessing (CBP) of AFEX-pretreated corn stover for ethanol production using Clostridium phytofermentans at a high solids loading. Biotechnol. Bioeng. 2012, 109, 1929-1936. [CrossRef] [PubMed]

104. Yee, K.L.; Rodriguez Jr, M.; Thompson, O.A.; Fu, C.; Wang, Z.-Y.; Davison, B.H.; Mielenz, J.R. Consolidated bioprocessing of transgenic switchgrass by an engineered and evolved Clostridium thermocellum strain. Biotechnol. Biofuels 2014, 7, 75. [CrossRef] [PubMed]

105. Schuster, B.G.; Chinn, M.S. Consolidated bioprocessing of lignocellulosic feedstocks for ethanol fuel production. Bioenergy Res. 2013, 6, 416-435. [CrossRef]

106. Ballesteros, M.; Manzanares, P. Liquid Biofuels. In The Role of Bioenergy in the Bioeconomy; Lago, C., Caldés, N., Lechón, Y., Eds.; Academic Press: Amsterdam, The Netherlands, 2019; pp. 113-144.

107. Bhatt, A.K.; Bhatia, R.K.; Thakur, S.; Rana, N.; Sharma, V.; Rathour, R.K. Fuel from waste: A review on scientific solution for waste management and environment conservation. In Prospects of Alternative Transportation Fuels; Singh, A.P., Agarwal, R.A., Agarwal, A.K., Dhar, A., Eds.; Springer: Singapore, 2018; pp. 205-233.

108. Wainaina, S.; Horvath, I.S.; Taherzadeh, M.J. Biochemicals from food waste and recalcitrant biomass via syngas fermentation: A review. Bioresour. Technol. 2018, 248, 113-121. [CrossRef] 
109. Lee, S.Y.; Sankaran, R.; Chew, K.W.; Tan, C.H.; Krishnamoorthy, R.; Chu, D.-T.; Show, P.-L. Waste to bioenergy: A review on the recent conversion technologies. BMC Energy 2019, 1, 4. [CrossRef]

110. García, M.P. Biorrefinerías: Situación Actual y Perspectivas de Futuro: Informe de Vigilancia Tecnológica; Genoma España; CIEMAT: Madrid, Spain, 2009. Available online: https://icono.fecyt.es/sites/default/ files/filepublicaciones/2009-biorrefinerias-pub_80_d.pdf (accessed on 1 September 2020).

111. García Martín, J.F.; Cuevas, M.; Feng, C.-H.; Mateos, P.A.; García, M.T.; Sánchez, S. Energetic valorisation of olive biomass: Olive-tree pruning, olive stones and pomaces. Processes 2020, 8, 511. [CrossRef]

112. Branco, R.; Serafim, L.; Xavier, A. Second generation bioethanol production: On the use of pulp and paper industry wastes as feedstock. Fermentation 2018, 5, 4. [CrossRef]

113. Chirat, C.; Lachenal, D.; Dufresne, A. Biorefinery in a kraft pulp mill: From bioethanol to cellulose nanocrystals. Cell Chem. Technol. 2010, 44, 59.

114. Martin-Sampedro, R.; Eugenio, M.E.; Moreno, J.A.; Revilla, E.; Villar, J.C. Integration of a kraft pulping mill into a forest biorefinery: Pre-extraction of hemicellulose by steam explosion versus steam treatment. Bioresour. Technol. 2014, 153, 236-244. [CrossRef] [PubMed]

115. Mendes, C.; Carvalho, M.; Baptista, C.; Rocha, J.; Soares, B.; Sousa, G. Valorisation of hardwood hemicelluloses in the kraft pulping process by using an integrated biorefinery concept. Food Bioprod. Process. 2009, 87, 197-207. [CrossRef]

116. Rodríguez-López, J.; Romaní, A.; González-Muñoz, M.J.; Garrote, G.; Parajó, J.C. Extracting value-added products before pulping: Hemicellulosic ethanol from Eucalyptus globulus wood. Holzforschung 2012, 66, 591-599. [CrossRef]

117. Devarapalli, M.; Atiyeh, H.K. A review of conversion processes for bioethanol production with a focus on syngas fermentation. Biofuel Res. J. 2015, 2, 268-280. [CrossRef]

118. Kumar, M.; Sun, Y.; Rathour, R.; Pandey, A.; Thakur, I.S.; Tsang, D.C.W. Algae as potential feedstock for the production of biofuels and value-added products: Opportunities and challenges. Sci. Total Environ. 2020, 716, 137116. [CrossRef]

119. Behera, S.; Singh, R.; Arora, R.; Sharma, N.K.; Shukla, M.; Kumar, S. Scope of algae as third generation biofuels. Front. Bioeng. Biotechnol. 2015, 2, 90. [CrossRef]

120. Ezejiofor, T.I.N.; Enebaku, U.E.; Ogueke, C. Waste to wealth-value recovery from agro-food processing wastes using biotechnology: A review. Biotechnol. J. Int. 2014, 4, 418-481. [CrossRef]

121. Jambo, S.A.; Abdulla, R.; Mohd Azhar, S.H.; Marbawi, H.; Gansau, J.A.; Ravindra, P. A review on third generation bioethanol feedstock. Renew. Sustain. Energy Rev. 2016, 65, 756-769. [CrossRef]

122. Sikarwar, V.S.; Zhao, M.; Fennell, P.S.; Shah, N.; Anthony, E.J. Progress in biofuel production from gasification. Prog. Energy Combust. Sci. 2017, 61, 189-248. [CrossRef]

123. Molino, A.; Larocca, V.; Chianese, S.; Musmarra, D. Biofuels production by biomass gasification: A review. Energies 2018, 11, 811. [CrossRef]

124. Rauch, R.; Hrbek, J.; Hofbauer, H. Biomass gasification for synthesis gas production and applications of the syngas. Wiley Interdiscip. Rev. Energy Environ. 2014, 3, 343-362. [CrossRef]

125. Subramani, V.; Gangwal, S.K. A review of recent literature to search for an efficient catalytic process for the conversion of syngas to ethanol. Energy Fuel 2008, 22, 814-839. [CrossRef]

126. Van der Heijden, H.; Ptasinski, K.J. Exergy analysis of thermochemical ethanol production via biomass gasification and catalytic synthesis. Energy 2012, 46, 200-210. [CrossRef]

127. Nda-Umar, U.; Ramli, I.; Taufiq-Yap, Y.; Muhamad, E. An overview of recent research in the conversion of glycerol into biofuels, fuel additives and other bio-based chemicals. Catalysts 2018, 9, 15. [CrossRef]

128. Gupta, M.; Kumar, N. Scope and opportunities of using glycerol as an energy source. Renew. Sustain. Energy Rev. 2012, 16, 4551-4556. [CrossRef]

129. Posada, J.; Cardona, C. Design and analysis of fuel ethanol production from raw glycerol. Energy 2010, 35, 5286-5293. [CrossRef]

130. Zheng, L.; Zhao, H.; Fu, J.; Lu, X.; Hou, Z. Direct production of ethanol from glycerol over Ni-substituted stichtite derived catalysts. Appl. Clay Sci. 2018, 153, 54-60. [CrossRef]

131. Amaral, P.F.F.; Ferreira, T.F.; Fontes, G.C.; Coelho, M.A.Z. Glycerol valorization: New biotechnological routes. Food Bioprod. Process. 2009, 87, 179-186. [CrossRef] 
132. Rutz, D.; Janssen, R.; Reumerman, P.; Spekreijse, J.; Matschegg, D.; Bacovsky, D.; Gröngröft, A.; Hauschild, S.; Dögnitz, N.; Karampinis, E.; et al. Technical Options for Retrofitting Industries with Bioenergy: A Handbook; WIP Renewable Energies: Munich, Germany, 2020. Available online: https:/www.biofit-h2020.eu/publicationsreports/BioFitHandbook-2020-03-18.pdf (accessed on 1 September 2020).

133. IEA. Database on Facilities for the Production of Advanced Liquid and Gaseous Biofuels for Transport; IEA Bioenergy: Paris, France, 2020. Available online: https://demoplants.bioenergy2020.eu/ (accessed on 1 September 2020).

134. Cheng, Z. Lignocellulosic ethanol: Technology and economics. In Alcohol Fuels Current Technologies and Future Prospect; Yun, Y., Ed.; IntechOpen: London, UK, 2019.

135. Lux-Research. Lux: Cellulosic Ethanol Price Hinges on Feedstock Cost; Ethanol Producer Magazine: Boston, MA, USA, 2016. Available online: http://ethanolproducer.com/articles/13085/lux-cellulosicethanol-price-hingeson-feedstock-cost (accessed on 1 September 2020).

136. EERE. POET-DSM: Project Liberty; Office of Energy Efficiency and Renewable Energy: Washington, DC, USA, 2015. Available online: https://www.energy.gov/eere/bioenergy/poet-dsm-project-liberty (accessed on 1 September 2020).

137. Joelsson, E.; Erdei, B.; Galbe, M.; Wallberg, O. Techno-economic evaluation of integrated first- and second-generation ethanol production from grain and straw. Biotechnol. Biofuels 2016, 9, 1. [CrossRef]

138. Macrelli, S.; Galbe, M.; Wallberg, O. Effects of production and market factors on ethanol profitability for an integrated first and second generation ethanol plant using the whole sugarcane as feedstock. Biotechnol. Biofuels 2014, 7, 26. [CrossRef]

139. Watanabe, M.D.B.; Chagas, M.F.; Cavalett, O.; Guilhoto, J.J.M.; Griffin, W.M.; Cunha, M.P.; Bonomi, A. Hybrid input-output Life Cycle Assessment of first- and second-generation ethanol production technologies in Brazil. J. Ind Ecol. 2016, 20, 764-774. [CrossRef]

140. Biorefinery2021. New Approaches Towards the Biorefinery of the Future. Cluster Biorefinery2021-Energy from Biomass; Biorefinery 2010: Hamburg, Germany, 2010. Available online: http://bioraffinerie2021.de/archiv/en/ Ziele.html (accessed on 1 September 2020).

141. Rutz, D.; Janssen, R.; van den Berg, N.; Reumerman, P.; Spekreijse, J.; Matschegg, D.; Bacovsky, D.; Gröngröft, A.; Karampinis, E.; Kourkoumpas, D.-S.; et al. Summary Paper for Policy Makers: Retrofitting Europe's Industry with Bioenergy; WIP Renewable Energies: Munich, Germany, 2019. Available online: https:// www.biofit-h2020.eu/files/pdfs/D2.6_BIOFIT\%20Summary_2019-11-25b.pdf (accessed on 1 September 2020).

142. BioRefineries-blog. Corn Fiber Ethanol-Examining 1.5G Technologies; BioRefineries Blog: Las Rozas, Spain, 2017. Available online: https://biorrefineria.blogspot.com/2017/04/corn-fiber-ethanol-examining-1.5gtechnologies-biorefineries.html (accessed on 1 September 2020).

143. D3MAX. D3MAX Technology; D3MAX: Grand Forks, ND, USA, 2017. Available online: https://www.d3maxllc. com/technology (accessed on 1 September 2020).

144. Padella, M.; O'Connell, A.; Prussi, M. What is still limiting the deployment of cellulosic ethanol? Analysis of the current status of the sector. Appl. Sci. 2019, 9, 4523. [CrossRef]

145. EERE. Leveraging First Generation Bioethanol Production Workshop Presentations; Office of Energy Efficiency and Renewable Energy: Washington, DC, USA, 2019. Available online: https:/www.energy.gov/eere/bioenergy/ leveraging-first-generation-bioethanol-production-workshop-presentations (accessed on 1 September 2020).

146. ICM. From Corn Fiber to Clean Fuel; ICM: Colwich, KS, USA, 2020. Available online: https://icminc.com/ process-technologies/gen-1-5-fiber-to-cellulosic-ethanol-technology/ (accessed on 1 September 2020).

147. De Jong, E.; Higson, A.; Walsh, P.; Wellisch, M. Bio-Based Chemicals Value Added Products from Biorefineries; IEA Bioenergy: Paris, France, 2012. Available online: https:/www.ieabioenergy.com/wp-content/uploads/2013/10/ Task-42-Biobased-Chemicals-value-added-products-from-biorefineries.pdf (accessed on 1 September 2020).

148. Kamm, B.; Kamm, M. Principles of biorefineries. Appl. Microbiol. Biotechnol. 2004, 64, 137-145. [CrossRef]

149. Arevalo-Gallegos, A.; Ahmad, Z.; Asgher, M.; Parra-Saldivar, R.; Iqbal, H.M.N. Lignocellulose: A sustainable material to produce value-added products with a zero waste approach-A review. Int. J. Biol. Macromol. 2017, 99, 308-318. [CrossRef]

150. E4tech; RE-CORD; WUR. From the Sugar Platform to Biofuels and Biochemicals. European Union: Final report for the European Commission Directorate-General Energy, Contract No. ENER/C2/423-2012/SI2.673791. 2015. Available online: http://ibcarb.com/wp-content/uploads/EC-Sugar-Platform-final-report.pdf (accessed on 1 September 2020). 
151. Gullón, P.; Conde, E.; Moure, A.; Domínguez, H.; Parajó, J.C. Selected process alternatives for biomass refining: A review. Open Agric. J. 2010, 4, 135-144. [CrossRef]

152. Bajwa, D.S.; Pourhashem, G.; Ullah, A.H.; Bajwa, S.G. A concise review of current lignin production, applications, products and their environmental impact. Ind. Crops Prod. 2019, 139, 111526. [CrossRef]

153. Ragauskas, A.J.; Beckham, G.T.; Biddy, M.J.; Chandra, R.; Chen, F.; Davis, M.F.; Davison, B.H.; Dixon, R.A.; Gilna, P.; Keller, M.; et al. Lignin valorization: Improving lignin processing in the biorefinery. Science 2014, 344, 1246843. [CrossRef] [PubMed]

154. Brännvall, E. Overview of pulp and paper processes. In Pulping Chemistry and Technology; Ek, M., Gellerstedt, G., Henriksson, G., Eds.; De Gruyter: Berlin, Germany; Boston, MA, USA, 2009; pp. 1-12.

155. Diaz, A.B.; Blandino, A.; Caro, I. Value added products from fermentation of sugars derived from agro-food residues. Trends Food Sci. Technol. 2018, 71, 52-64. [CrossRef]

156. Climent, M.J.; Corma, A.; Iborra, S. Converting carbohydrates to bulk chemicals and fine chemicals over heterogeneous catalysts. Green Chem. 2011, 13, 520-540. [CrossRef]

157. Werpy, T.; Petersen, G. Top Value Added Chemicals from Biomass: Volume I-Results of Screening for Potential Candidates from Sugars and Synthesis Gas; Report No. DOE/GO-102004-1992; US Department of Energy Office of Scientific and Technical Information: Oak Ridge, TN, USA, 2004. Available online: https: //www.osti.gov/biblio/15008859 (accessed on 1 September 2020).

158. Stichnothe, H.; Bell, G.; Jorgensen, H.; De Bari, I.; Lindorfer, J.; Kepler, J.; de Jong, E. Bio-Based Chemicals: A 2020 Update; IEA Bioenergy: Paris, France, 2020. Available online: https:/www.ieabioenergy.com/wp-content/ uploads/2020/02/Bio-based-chemicals-a-2020-update-final-200213.pdf (accessed on 1 September 2020).

159. Tracy, B.P.; Jones, S.W.; Fast, A.G.; Indurthi, D.C.; Papoutsakis, E.T. Clostridia: The importance of their exceptional substrate and metabolite diversity for biofuel and biorefinery applications. Curr. Opin. Biotechnol. 2012, 23, 364-381. [CrossRef]

160. Ur-Rehman, S.; Mushtaq, Z.; Zahoor, T.; Jamil, A.; Murtaza, M.A. Xylitol: A review on bioproduction, application, health benefits, and related safety issues. Crit. Rev. Food Sci. Nutr. 2015, 55, 1514-1528. [CrossRef]

161. John, R.P.; Nampoothiri, K.M.; Pandey, A. Fermentative production of lactic acid from biomass: An overview on process developments and future perspectives. Appl. Microbiol. Biotechnol. 2007, 74, 524-534. [CrossRef]

162. Lin, S.K.C.; Du, C.; Koutinas, A.; Wang, R.; Webb, C. Substrate and product inhibition kinetics in succinic acid production by Actinobacillus succinogenes. Biochem. Eng. J. 2008, 41, 128-135. [CrossRef]

163. Jung, I.-Y.; Lee, J.-W.; Min, W.-K.; Park, Y.-C.; Seo, J.-H. Simultaneous conversion of glucose and xylose to 3-hydroxypropionic acid in engineered Escherichia coli by modulation of sugar transport and glycerol synthesis. Bioresour. Technol. 2015, 198, 709-716. [CrossRef] [PubMed]

164. Marques, C.; Tarek, R.; Sara, M.; Brar, S.K. Sorbitol production from biomass and its global market. In Platform Chemical Biorefinery; Kaur Brar, S., Jyoti Sarma, S., Pakshirajan, K., Eds.; Elsevier: Amsterdam, The Netherlands, 2016; pp. 217-227.

165. Bozell, J.J.; Petersen, G.R. Technology development for the production of biobased products from biorefinery carbohydrates-The US Department of Energy's “Top 10" revisited. Green Chem. 2010, 12, 539-554. [CrossRef]

166. Mamman, A.S.; Lee, J.-M.; Kim, Y.-C.; Hwang, I.T.; Park, N.-J.; Hwang, Y.K.; Chang, J.-S.; Hwang, J.-S. Furfural: Hemicellulose/xylosederived biochemical. Biofuel Bioprod. Biorefin. 2008, 2, 438-454. [CrossRef]

167. Azadi, P.; Inderwildi, O.R.; Farnood, R.; King, D.A. Liquid fuels, hydrogen and chemicals from lignin: A critical review. Renew. Sustain. Energy Rev. 2013, 21, 506-523. [CrossRef]

168. Yuan, T.-Q.; Xu, F.; Sun, R.-C. Role of lignin in a biorefinery: Separation characterization and valorization. J. Chem. Technol. Biotechnol. 2013, 88, 346-352. [CrossRef]

169. L'udmila, H.; Michal, J.; Andrea, Š.; Aleš, H. Lignin, potential products and their market value. Wood Res. 2015, 60, 973-986.

170. Martín-Sampedro, R.; Santos, J.I.; Eugenio, M.E.; Wicklein, B.; Jiménez-López, L.; Ibarra, D. Chemical and thermal analysis of lignin streams from Robinia pseudoacacia L. generated during organosolv and acid hydrolysis pre-treatments and subsequent enzymatic hydrolysis. Int. J. Biol. Macromol. 2019, 140, 311-322.

171. Sannigrahi, P.; Pu, Y.; Ragauskas, A. Cellulosic biorefineries-Unleashing lignin opportunities. Curr. Opin. Environ. Sustain. 2010, 2, 383-393. [CrossRef] 
172. Li, C.; Zhao, X.; Wang, A.; Huber, G.W.; Zhang, T. Catalytic transformation of lignin for the production of chemicals and fuels. Chem. Rev. 2015, 115, 11559-11624. [CrossRef] [PubMed]

173. Kirkels, A.F.; Verbong, G.P.J. Biomass gasification: Still promising? A 30-year global overview. Renew. Sustain. Energy Rev. 2011, 15, 471-481. [CrossRef]

174. Santos, R.G.D.; Alencar, A.C. Biomass-derived syngas production via gasification process and its catalytic conversion into fuels by Fischer Tropsch synthesis: A review. Int. J. Hydrog. Energy 2020, 45, 18114-18132. [CrossRef]

175. Liakakou, E.T.; Vreugdenhil, B.J.; Cerone, N.; Zimbardi, F.; Pinto, F.; André, R.; Marques, P.; Mata, R.; Girio, F. Gasification of lignin-rich residues for the production of biofuels via syngas fermentation: Comparison of gasification technologies. Fuel 2019, 251, 580-592. [CrossRef]

176. Tomás-Pejó, E.; Fermoso, J.; Herrador, E.; Hernando, H.; Jiménez-Sánchez, S.; Ballesteros, M.; González-Fernández, C.; Serrano, D.P. Valorization of steam-exploded wheat straw through a biorefinery approach: Bioethanol and bio-oil co-production. Fuel 2017, 199, 403-412. [CrossRef]

177. Luo, H.; Abu-Omar, M.M. Chemicals from Lignin. In Encyclopedia of Sustainable Technologies; Abraham, M.A., Ed.; Elsevier: Oxford, UK, 2017; pp. 573-585.

178. Smolarski, N. High Value Opportunities for Lignin. Unlocking Its Potential; Frost and Sullivan: Mountain View, CA, USA, 2012. Available online: https:/www.greenmaterials.fr/wp-content/uploads/2013/01/High-valueOpportunities-for-Lignin-Unlocking-its-Potential-Market-Insights.pdf (accessed on 1 September 2020).

179. Wang, H.; Pu, Y.; Ragauskas, A.; Yang, B. From lignin to valuable products-Strategies, challenges, and prospects. Bioresour. Technol. 2019, 271, 449-461. [CrossRef]

180. Yie, H.; Sun, M.M.; Zhu, Z.; Chen, P.; Li, Y.; Taube, W.; Zhu, Z.; Gong, J.; Wu, J. Patent EP 2006354 A2. In Novel Method for Production Liquid Fuel from Biomass; Pficker Pharmaceuticals Ltd.: New York, NY, USA, 2007.

181. Das, L.; Kolar, P.; Sharma-Shivappa, R. Heterogeneous catalytic oxidation of lignin into value-added chemicals. Biofuels 2012, 3, 155-166. [CrossRef]

182. Liu, S.; Shi, Z.; Li, L.; Yu, S.; Xie, C.; Song, Z. Process of lignin oxidation in an ionic liquid coupled with separation. RSC Adv. 2013, 3, 5789-5793. [CrossRef]

183. Xu, W.; Li, X.; Shi, J. Oxidative depolymerization of cellulolytic enzyme lignin over silicotungvanadium polyoxometalates. Polymers 2019, 11, 564. [CrossRef]

184. Picart, P.; Liu, H.; Grande, P.M.; Anders, N.; Zhu, L.; Klankermayer, J.; Leitner, W.; Domínguez de María, P.; Schwaneberg, U.; Schallmey, A. Multi-step biocatalytic depolymerization of lignin. Appl. Microbiol. Biotechnol. 2017, 101, 6277-6287. [CrossRef] [PubMed]

185. Liu, W.-J.; Jiang, H.; Yu, H.-Q. Thermochemical conversion of lignin to functional materials: A review and future directions. Green Chem. 2015, 17, 4888-4907. [CrossRef]

186. Martín-Sampedro, R.; Eugenio, M.E.; Fillat, Ú.; Martín, J.A.; Aranda, P.; Ruiz-Hitzky, E.; Ibarra, D.; Wicklein, B. Biorefinery of lignocellulosic biomass from an elm clone: Production of fermentable sugars and lignin-derived biochar for energy and environmental applications. Energy Technol. 2019, 7, 277-287. [CrossRef]

187. Collins, M.N.; Nechifor, M.; Tanasă, F.; Zănoagă, M.; McLoughlin, A.; Stróżyk, M.A.; Culebras, M.; Teacă, C.-A. Valorization of lignin in polymer and composite systems for advanced engineering applications-A review. Int. J. Biol. Macromol. 2019, 131, 828-849. [CrossRef] [PubMed]

188. Kalami, S.; Arefmanesh, M.; Master, E.; Nejad, M. Replacing $100 \%$ of phenol in phenolic adhesive formulations with lignin. J. Appl. Polym. Sci. 2017, 134, 45124. [CrossRef]

189. Mahmood, N.; Yuan, Z.; Schmidt, J.; Xu, C. Depolymerization of lignins and their applications for the preparation of polyols and rigid polyurethane foams: A review. Renew. Sustain. Energy Rev. 2016, 60, 317-329. [CrossRef]

190. Borrero-López, A.M.; Martín-Sampedro, R.; Ibarra, D.; Valencia, C.; Eugenio, M.E.; Franco, J.M. Evaluation of lignin-enriched side-streams from different biomass conversion processes as thickeners in bio-lubricant formulations. Int. J. Biol. Macromol. 2020, 162, 1398-1413. [CrossRef] [PubMed]

191. Vashist, A.; Vashist, A.; Gupta, Y.K.; Ahmad, S. Recent advances in hydrogel based drug delivery systems for the human body. J. Mater. Chem. B 2014, 2, 147-166. [CrossRef] [PubMed]

192. Duval, A.; Lawoko, M. A review on lignin-based polymeric, micro- and nano-structured materials. React Funct. Polym. 2014, 85, 78-96. [CrossRef] 
193. Mandlekar, N.; Cayla, A.; Rault, F.; Giraud, S.; Salaün, F.; Malucelli, G.; Guan, J.-P. An overview on the use of lignin and its derivatives in fire retardant polymer systems. In Lignin-Trends and Applications; Poletto, M., Ed.; IntechOpen: London, UK, 2018.

194. Mozaffarian, H. Development of Advanced Biorefinery Schemes to be Integrated into Existing Industrial Fuel Complexes; Energy Research Centre of The Netherlands: Petten, The Netherlands, 2010. Available online: https: //www.bioref-integ.eu/fileadmin/bioref-integ/user/documents/Brochure.pdf (accessed on 1 September 2020).

195. De Bari, I.; Cuna, D.; Di Fidio, N. Biorefineries: Biofuels, biochemicals, and bioproducts. In Biofuels Production and Processing Technology; Riazi, M.R., Chiaramonti, D., Eds.; CRC Press: Boca Raton, FL, USA, 2017; pp. 533-568.

Publisher's Note: MDPI stays neutral with regard to jurisdictional claims in published maps and institutional affiliations.

(C) 2020 by the authors. Licensee MDPI, Basel, Switzerland. This article is an open access article distributed under the terms and conditions of the Creative Commons Attribution (CC BY) license (http://creativecommons.org/licenses/by/4.0/). 